\title{
Transcriptional analysis of sodium valproate in a serotonergic cell line reveals gene regulation through both HDAC inhibition-dependent and independent mechanisms
}

Priyanka Sinha $^{1,2}$, Simone Cree ${ }^{1,2}$, Allison L. Miller ${ }^{1,2}$, John F. Pearson ${ }^{1,2,3}$, Martin A. Kennedy ${ }^{1,2}$.

${ }^{1}$ Gene Structure and Function Laboratory, Department of Pathology and Biomedical Science, University of Otago, Christchurch, New Zealand.

${ }^{2}$ Carney Centre for Pharmacogenomics, University of Otago, Christchurch, New Zealand.

${ }^{3}$ Biostatistics and Computational Biology Unit, University of Otago, Christchurch, New Zealand.

Correspondence to:

Prof. M. A. Kennedy

Department of Pathology and Biomedical Science

University of Otago, Christchurch

Christchurch, New Zealand

Email: martin.kennedy@otago.ac.nz

Keywords: RNA-Seq, NanoString, lithium, valproate, HDAC inhibitor, mood stabilizer 


\begin{abstract}
Sodium valproate (VPA) is a histone deacetylase (HDAC) inhibitor, widely prescribed in the treatment of bipolar disorder, and yet the precise modes of therapeutic action for this drug are not fully understood. After exposure of the rat serotonergic cell line RN46A to VPA, RNA-sequencing (RNA-Seq) analysis showed widespread changes in gene expression. Analysis by multiple pipelines revealed as many as 230 genes were significantly upregulated and 72 genes were significantly downregulated. A subset of 23 differentially expressed genes was selected for validation using the nCounter® platform, and of these we obtained robust validation for ADAM23, LSP1, MAOB, MMP13, PAK3, SERPINB2, SNAP91, WNT6, and ZCCHC12. We investigated the effect of lithium on this subset and found four genes, CDKN1C, LSP1, SERPINB2 and WNT6 co-regulated by lithium and VPA. We also explored the effects of other HDAC inhibitors and the VPA analogue valpromide on the subset of 23 selected genes. Expression of eight of these genes, CDKNIC, MAOB, MMP13, NGFR, SHANK3, VGF, WNT6 and ZCCHC12, was modified by HDAC inhibition, whereas others did not appear to respond to several HDAC inhibitors tested. These results suggest VPA may regulate genes through both HDAC-dependent and independent mechanisms. Understanding the broader gene regulatory effects of VPA in this serotonergic cell model should provide insights into how this drug works and whether other HDACi compounds may have similar gene regulatory effects, as well as highlighting molecular processes that may underlie regulation of mood.
\end{abstract}

\title{
Introduction
}

Sodium valproate (VPA) is a histone deacetylase inhibitor (HDACi) [1, 2], and is widely used in the treatment of bipolar disorder (BD) [3]. The mechanism of action of VPA as a mood stabilizer is not well understood. VPA has been shown to affect the serotonergic [4, 5], dopaminergic [6], GABAergic [7] and glutamatergic [8-10] pathways as well as intracellular signalling pathways such as those mediated by phosphoinositol $[11,12]$, glycogen kinase-3ß/Wnt [13], protein kinase C [14], and ERK/MAPK [15, 16] among others [17-19].

Previous attempts to find differential gene expression effects of the drug have focused mostly on a handful of candidate genes [6, 20-25]. Subsequently, microarrays were used to study the gene expression effects of VPA in neuroblastoma or glioma cell lines [26-32]. Microarrays are limited to identifying transcripts targeted by their probe sets, limiting their ability to detect novel transcripts. In contrast, RNA-Seq has the capacity to capture transcripts from both protein-coding and non-coding genes, which have been shown to be important transcriptional regulators. VPA has been shown to target multiple genes and pathways [26, 27, 31,33-36], therefore a whole transcriptomic approach is well suited to better understand potential mechanisms of action. 
Dysregulation of the serotonergic system has been implicated in the pathophysiology of mood disorders [18]. The serotonergic neurons originate from the median and the dorsal raphe nucleus in the brain stem and project to different brain regions, where they secrete serotonin which regulates mood [37]. In this study, we examined the gene expression effects of VPA using the neural cell line RN46A, derived from the rat medullary raphe region [38], which has been used previously to study gene expression in response to antidepressants and mood stabilisers [39-44]. Differentiated RN46A cells express all 5-HT receptors 5-HT1A, 5-HT1B, 5-HT2A and 5-HT2C and the serotonin transporter SERT [38, 45].

Understanding the transcriptional effects of VPA in a relevant cellular context may provide clues to its mechanisms of action. Previous studies in our laboratory using the RN46A cell line revealed differential gene expression in response to VPA exposure $[41,44]$. In this paper, we sought to extend these findings using RNA-Seq as a discovery tool for differentially expressed genes (DEG), followed by validation of a subset of these genes using an orthogonal gene expression analysis method. Furthermore, we examined the action of other mood stabilizing drugs and other HDACi compounds on expression of this subset of genes.

\section{Methods}

\section{Cell culture and RNA extraction}

The RN46A cells were maintained at $33^{\circ} \mathrm{C}$ in Dulbecco's Modified Eagle Medium: Nutrient Mixture F12 (DMEM/F12; ThermoFisher Scientific, MA, USA) containing glutamine (GlutaMAX ${ }^{\mathrm{TM}_{-} \mathrm{I} \text {; }}$ ThermoFisher Scientific, MA, USA) and supplemented with 5\% fetal bovine serum (FBS) and 250 $\mu \mathrm{g} / \mathrm{ml}$ Geneticin G418 (ThermoFisher Scientific, MA, USA). For differentiation, RN46A cells were seeded in plates coated with $100 \mu \mathrm{g} / \mathrm{cm}^{2}$ collagen (Sigma-Aldrich, St. Louis, MO, USA) and $1 \mu \mathrm{g} / \mathrm{cm}^{2}$ fibronectin (Sigma-Aldrich, St. Louis, MO, USA), and confluent RN46A cultures were shifted to $39^{\circ} \mathrm{C}$ and supplemented with DMEM/F-12 containing 1\% FBS, 1\% BSA, 1\% N2 supplement, $0.75 \mathrm{~g} / \mathrm{L}$ sodium pyruvate and $0.073 \mathrm{~g} / \mathrm{L} \mathrm{L-glutamine.} \mathrm{RN46A} \mathrm{cells} \mathrm{were} \mathrm{differentiated} \mathrm{for} 72 \mathrm{~h}$ and then drug exposed for $72 \mathrm{~h}$.

Differentiated RN46A cells were exposed to either $0.5 \mathrm{mM}$ VPA or $0.5 \mathrm{mM}$ lithium chloride for $72 \mathrm{~h}$. Three factors guided the concentration of lithium and VPA chosen in this study: plasma levels measured in patients undergoing treatment [8, 46-48], prior levels used in published in vitro [49-53] and in vivo studies [54-57], and prior levels used in studies from our laboratory [41, 44]. For RNASeq, cells cultured with differentiation medium were used as control.

Total RNA was isolated using Trizol® (ThermoFisher Scientific, MA, USA), according to the manufacturer's instructions. Quality control was performed using the Agilent 2200 TapeStation system (Agilent Technologies, Santa Clara, CA, USA). RNA samples with 260/280 and 260/230 ratios of $\sim 2$ 
and RIN score greater than 7 were shipped to Novogene (Beijing, China) for RNA-Seq. The drug exposure experiments were repeated three times and RNA samples from all three experiments were sent for sequencing.

For validation of RNA-Seq data, the nCounter® platform (NanoString, Seattle, WA, USA) was used in two successive runs, each using RNA derived from independent cell culture experiments. VPA is a major class I HDACi [1] so in the first run, we tested whether a similar broad range HDACi (trichostatin A) could affect gene expression, and in the second run, selective $\operatorname{HDAC}$ 1, 3 and 8 inhibitors were used. In Run 1, differentiated RN46A cells were exposed to $0.5 \mathrm{mM}$ VPA, $1 \mathrm{mM}$ lithium, $0.5 \mathrm{mM}$ valpromide (VPD) and 30nM trichostatin A (TSA) (Supplementary Table 1). In Run 2, differentiated RN46A cells were exposed to 0.5mM VPA, $2 \mathrm{mM}$ lithium, $0.5 \mathrm{mM}$ VPD, $0.5 \mu \mathrm{M}$ CI994 (HDAC1 inhibitor), $0.08 \mu \mathrm{M}$ RGFP966 (HDAC3 inhibitor),, 0.01 $\mu$ M PCI-34051 (HDAC8 inhibitor) and 0.015 $\mu \mathrm{M}$ tubastatin A (HDAC6 inhibitor) for $72 \mathrm{~h}$ (Supplementary Table 1). For all nCounter® experiments, cells cultured with differentiation medium containing $0.05 \%$ DMSO were used as controls.

For nCounter® experiments, direct-zol ${ }^{\mathrm{TM}}$ RNA miniprep kit (Zymogen, Irvine, CA, USA) was used for total RNA extraction according to the manufacturer's instructions. nCounter ${ }^{\circledR}$ mRNA gene expression assays were carried out by New Zealand Genomics Limited (Dunedin, New Zealand). Based on the nCounter ${ }^{\circledR}$ custom code design, the drug exposure experiments were repeated four times for Run1 samples and three times for Run2 samples.

\section{RNA-Seq analysis}

RNA-Seq was carried out on the Illumina HiSeq ${ }^{\mathrm{TM}} 2500$ platform (Illumina inc. San Diego, CA, USA) by Novogene (Beijing, China). 125 bp paired-end sequencing generated $>16$ million reads per sample, which were mapped to the Rat Rnor6 reference genome (ENSEMBL, Jul 2014, version 88) with the splice-aware STAR aligner (v2.5.1.b) [58]. In addition, reads were mapped to the rat transcriptome with kallisto (v0.42.4) [59] and salmon (v0.6.1) [60]. Mapping quality data using STAR, kallisto and salmon software are summarized in Supplementary Table 2, 3 and 4, respectively.

Four pipelines were used for DEG analysis (Figure 1): DESeq2 [61], cufflinks2.2.1 suite [62, 63], kallisto-sleuth [59] and salmon-sleuth [59, 60]. Salmon output was converted into sleuth-compatible format using wasabi [60]. Genes with a cut-off adjusted p-values (padj) $<0.05$ and $\log 2$ fold change $(\log 2 \mathrm{FC}) \geq 1.5$ fold were considered to be differentially expressed.

\section{Figure 1 near here.}

\section{Functional enrichment and pathway analysis}

Integrated differential expression and pathway analysis (iDEP) web-based tool (v 0.80) [64] was used for functional enrichment and pathway analysis. Read count data from STAR aligner for three VPAtreated and three untreated control samples were uploaded to the website. Differential expression 
analysis was carried out with DESeq2. The count data were rlog transformed [61] using the edgeR [65] tool for further clustering analysis and principal component analysis. Enrichment analysis was carried out on DEG from the VPA exposure experiments using GO and available gene sets with the iDEP web tool [64]. Pathway analysis was carried out with the GSEA method and KEGG database using the iDEP web tool.

\section{nCounter ${ }^{\circledR}$ data analysis}

Raw data from the reporter code count (RCC) files were analysed with nSolver ${ }^{\mathrm{TM}}$ v3.0. The mRNA counts were normalized with a geometric mean of positive controls, geometric mean of negative controls and geometric mean of housekeeping genes (G6PD and MAPKO). One-tailed heteroscedastic Welch's t-test was used for DE analysis.

The R package, NanoStringDiff ( $v$ 1.8.1), was used for normalization of raw nCounter ${ }^{\circledR}$ data and DE analysis [66]. Empirical Bayes shrinkage was used to estimate dispersion parameters and counts were modeled using the negative binomial distribution. A generalized linear model (GLM) maximum likelihood ratio test was used for DE analysis and chi-square approximation for calculating p-values. The Benjamini-Hochberg method was used for calculating FDR [67].

\section{Results}

\section{Differential gene expression analysis in response to VPA and lithium}

In this study, RNA-Seq was used to examine global gene expression changes in differentiated RN46A cells exposed to VPA and lithium. A total of 19,774 genes from STAR alignment were used for differential expression analysis with DESeq2 and cufflinks2 suite whereas 10,394 and 10,134 genes were used after pseudo-alignment with kallisto-sleuth and salmon-sleuth, respectively. Genes with padj $<0.05$ and $\log 2 \mathrm{FC} \geq 1.5$ fold were considered as significantly regulated (DEG). Using these criteria, in response to VPA, 224 DEGs were observed with DESeq2 (Supplementary Table 5), 144 with kallisto (Supplementary Table 6), 158 with salmon (Supplementary Table 7) and 302 with cuffdiff2 (Supplementary Table 8). A four-way comparison showed that a total of 67 DEGs were common among the four tools, whereas 151 genes were common between the whole genome (DESeq2 and cuffidiff2) and 111 genes between the transcriptome (salmon and kallisto) differential expression analysis tools (Figure 2).

The top 25 DEGs in response to $0.5 \mathrm{mM}$ VPA as identified with DESeq2 are listed in Table 1. In comparison, exposure of RN46A cells to $0.5 \mathrm{mM}$ lithium resulted in no genes showing significant expression differences in the RNA-Seq analysis.

\section{Table 1 near here}

Figure 2 near here 


\section{Functional enrichment and pathway analysis}

iDEP web-based tool v0.80 [64] was used for functional enrichment and pathway analysis for VPA exposure. Read count data from STAR-aligner was analyzed with DESeq2 and a total of 985 genes was selected at FDR of 0.1 and fold change of 2, with 712 up-regulated and 273 down-regulated genes. The most significant GO processes and pathways are summarized in Supplementary Table 9 for upregulated genes and Supplementary Table 10 for downregulated genes. Both the GO processes and pathways for the upregulated genes were highly enriched in neuronal development and function. For the downregulated genes, the GO processes were enriched in response to environmental stimuli, however, the pathways were enriched in chromatin and nucleosome assembly (associated with HDACi effects of VPA).

\section{Validation of RNA-Seq results with nCounter® assay}

The nCounter® assay format chosen for independent validation of DEGs identified in RNA-Seq required that we focus on a relatively small subset of DEG. Therefore, 23 VPA-regulated genes (Supplementary Table 11) were selected for validation. The selection process began with those genes that showed high fold change and strong statistical significance in the RNA-Seq data. The expression characteristics of each candidate DEG for validation were then examined in the Genotype-Tissue Expression (GTEx) [68] and Allen brain atlas in-situ hybridisation [69] databases, and brain-expressed genes were preferentially selected (Supplementary Table 12).

Of the 23 genes in the nCounter® assay panel, 12 genes were found to be altered by VPA in Run 1 and 17 genes in Run2 as identified with both analysis methods (Table 2). Taken together, six genes replicated as VPA DEGs in both Run1 and Run2, using both nSolver ${ }^{\mathrm{TM}}$ and nanoStringDiff software (Table 2). These were SNAP91, ADAM23, LSP1, ZCCHC12, PAK3 and MMP13. Other genes with high confidence included MAOB, SERPINB2 and WNT6. All the gene expression changes were in the same direction between RNA-Seq and nCounter® platforms, and showed similar magnitude.

\section{Table 2 near here}

\section{Lithium}

No significant gene expression changes in the RNA-Seq data were observed with exposure of the RN46A cell line to $0.5 \mathrm{mM}$ lithium. This concentration of lithium was judged to be quite low for RN46A cells, and therefore was increased to $1 \mathrm{mM}$ and $2 \mathrm{mM}$ in nCounter ${ }^{\circledR}$ Run1 and Run2, respectively. After exposure to $1 \mathrm{mM}$ lithium in Run 1, expression of CDKN1C was significantly changed and in Run 2, $2 \mathrm{mM}$ lithium resulted in significant expression changes for three genes (LSP1, SERPINB2 and WNT6) (Table 3). When analysed with NanoStringDiff, two genes (CDKNIC and SERPIN2B) showed altered expression in Run1 and six genes (LSP1, SERPIN2B, WNT6, MAOB, CNTN1 and ADAM23) showed altered expression in Run2. 


\section{Table 3 near here}

\section{Gene regulation by HDAC inhibitors}

The effects of several different HDACi on expression of the selected subset of genes were evaluated using the nCounter® assay in two separate runs. $\log 2 \mathrm{FC}$ and $\mathrm{p}$-value for the 23 genes after exposure of RN46A cells to VPA, VPD and TSA in Run 1 are shown in Table 4. $\log 2 \mathrm{FC}$ and p-value for the 23 genes after exposure of RN46A cells to VPA, VPD and CI994 in Run2 are shown in Table 5, and RGFP966, PCI34051 and tubastatin A in Run2 are shown in Supplementary Table 13. Genes with $\log 2 \mathrm{FC}>0.5$ and $\mathrm{p}$-value $<0.05$ were considered to be differentially expressed (DEG).

After exposure to VPD, CDKNIC and WNT6 were upregulated, and MMP13 and SERPINB2 were downregulated by VPD as identified with both nSolver ${ }^{\mathrm{TM}}$ and NanoStringDiff in Run1 (Table 4). In Run2, only LSP1 was a DEG as identified with both tools (Table 5). However, ADAM23, CACNA1B, CDKNIC, IGF2, LINGO1, NOTCH3, SNAP91, VGF and WNT6 were identified as DEG with NanoStringDiff only.

MMP13 and VGF were upregulated whereas ZCCHC12 was downregulated in response to TSA as identified with both tools. NOTCH3 was upregulated and SHANK3 was downregulated by TSA as identified with NanoStringDiff only. After exposure to CI994, only $M A O B$ was a DEG as identified with both nSolver ${ }^{\mathrm{TM}}$ and NanoStringDiff (Table 5). However, CDKN1C, NGFR, WNT6 and ZCCHC12 were identified as DEG with NanoStringDiff only.

No DEG were identified for PCI34051 and tubastatin A exposure using either or both analysis tools (Supplementary Table 13). However, for RGFP966 exposure, SNAP91 was identified as differentially expressed with NanoStringDiff only (Supplementary Table 13).

Table 4 near here

Table 5 near here

\section{Discussion}

This study examined the global profile of gene expression effects of VPA and lithium, using RNA-Seq analysis, and more targeted effects of various drugs and HDACi on a subset of genes, in a serotonergic context. The RN46A cell line is derived from the medullary raphe nucleus, which along with the dorsal raphe nucleus is the serotonergic centre of the brain, which has been implicated in mood disorders and their treatment [70]. Upon differentiation, RN46A cells acquire a neuronally restricted morphology and express $\mathrm{p} 75^{\mathrm{NGFR}}$ and trkB receptors, neurofilament (NF-L, NF-M and NF-H), vimentin and nestin [38]. Therefore, we used this cell line as an in vitro model to explore expression changes that may occur within cells of the serotonergic system of the brain, after exposure to VPA. 
The RNA-Seq analysis revealed that VPA resulted in extensive gene expression changes. To add confidence, we used four RNA-Seq analytical pipelines with freely-available and widely-used tools, and compared the different RNA-Seq workflows. There was variation in methodology among differential gene expression analysis tools including the choice of normalization method, density distribution and tests for differential expression such as t-test vs generalized linear models. Thus, each bioinformatic tool called different numbers of DEGs with cuffdiff2 producing the highest number, and kallisto and salmon producing similar numbers. A four-way comparison showed that a total of 67 DEGs were in common among the four DEA tools, and a two-way comparison to clarify relationships between the whole genome (and transcriptome) DEA tools showed that 151 DEGs were in common to DESeq2 and cuffdiff2, and 111 genes were in common to salmon and kallisto (Figure 2). The extensive gene expression changes seen with VPA in this model system are of interest. In part this may reflect the action of HDAC inhibitors on chromatin modifications, which has the potential to alter regulation of many genes. The widespread gene expression changes may also be relevant to the significant side effects that can occur with VPA, particularly teratogenicity $[1,71,72]$.

In comparison, no significant gene expression changes were observed in the RNA-Seq data with lithium. A similar observation was made in a previous RNA-Seq analysis of lithium-treated undifferentiated RN46A cells [41]. With the same concentration and exposure time, only three genes were significantly altered with the same criteria $(\log 2 \mathrm{FC}>1.5$ and FDR $<0.05)$. This suggested $0.5 \mathrm{mM}$ lithium may be too low to trigger gene expression changes in this cell line. In other cells, lithium concentrations as high as 10mM have been used [73], and in the SK-N-AS neuronal cell line, no change in synapsin $2 \mathrm{a}$ mRNA levels was seen at $0.5 \mathrm{mM}$ lithium, but it was differentially expressed with exposure to either 1.0 or $2.0 \mathrm{mM}$ lithium [74].

Twenty-three DEGs from the RNA-Seq analysis of VPA-treated RN46A cells were selected for validation with the $\mathrm{nCounter}{ }^{\circledR}$ assay in two separate runs. Two software packages nSolver ${ }^{\mathrm{TM}} \mathrm{v} 3.0$ and nanoStringDiff were used for normalization and differential expression analysis. Twelve genes were found to be altered by VPA in Run1 and 17 genes in Run2 (Table 2) as identified with both analysis methods. Although there were some differences in DEG detected between the two runs, which were carried out independently, there was significant overlap and the direction of change was the same for all significant genes between runs, with comparable fold-changes. VPA results were reproducible across runs with slight variation due to the software used for analysis.

\section{Functional enrichment and pathway analysis}

Functional enrichment analysis such as GO analysis characterizes a phenotype by identifying overrepresented/enriched categories of genes that share a similar function within the list of DEGs. Biologically relevant signals may be detected by pathway analysis wherein genes are analysed in functional groups, networks or pathways. 
The most-enriched GO processes for VPA regulated genes indicated the relevance to mood regulation of the genes identified in this RNA-Seq study (Supplementary Table 9). GO analysis highlighted biological processes "nervous system development" and "neurogenesis" as the most-enriched GO processes. Reduced neurogenesis has been linked to mood disorders $[75,76]$ and the therapeutic effect of antidepressants has been partly attributed to increased hippocampal neurogenesis [77-79]. Reduced hippocampal volume was observed in major depressive disorder and BD patients [80] which could be restored with mood stabilizers and antidepressants [81-83]. VPA has been shown to affect neuron differentiation and nervous system development [84-87], and similar biological processes such as neuron differentiation, projection and development were observed as the most-enriched in functional enrichment analyses of DEGs and differentially methylated regions in BD post-mortem brain [88].

VPA-regulated genes were analysed with the gene set enrichment analysis (GSEA) method [89] using the iDEP web tool. The top up-regulated pathway was cell adhesion molecules (Supplementary Table 9). ECM remodelling and synaptic plasticity dysfunction have been implicated in the pathophysiology of BD and schizophrenia [90-93]. Cell adhesion genes were most differentially regulated in response to VPA and matrix metalloproteinases such as $M M P 13, M M P 9$ and $M M P 12$ were some of the genes highly upregulated by VPA. MMP13 and MMP12 were also upregulated by VPA in our prior RNA-Seq study with undifferentiated RN46A cells [41]. Other top up-regulated pathways were involved in GABAergic and serotonergic synapse suggesting that VPA up-regulated genes might be relevant to its moodstabilizing effect.

\section{Co-regulated genes}

Genes co-regulated by lithium and VPA, two structurally dissimilar mood stabilizers, are potentially relevant to mood stabilizing effects and may highlight important pathways in the mechanism of action for these drugs. Prior studies have identified some genes and pathways that overlap between lithium and VPA [32, 41, 94-96]. Four genes were clearly identified to be co-regulated by lithium and VPA: CDKN1C, LSP1, SERPINB2 and WNT6. CDKNIC is a maternally imprinted gene regulated by HDAC inhibitors [97] and linked with neurogenesis in the developing brain [98]. LSP1 is expressed in monocytes, neutrophils, macrophages as well as neuropils and may be linked to neuroinflammation in the brain. Both mania and depression are associated with increased pro-inflammatory cytokines secreted by macrophages, T-lymphocytes and endothelial cells, and decreased anti-inflammatory markers [99103]. SERPINB2 is involved in cell proliferation, differentiation and growth and regulates synaptic plasticity in hippocampal neurons [104]. Reduced synaptic plasticity is observed in BD [105, 106] and antidepressants have been shown to enhance neuroplasticity and resilience [77-79]. Wnt proteins regulate several processes such as brain development, cell growth, differentiation, migration and fate determination among others, implicated in BD pathophysiology. Both lithium and VPA affect expression of Wnt signalling pathway genes [107, 108]. Further study is needed to examine the role of these co-regulated genes in mood regulation. 


\section{Gene regulation by other HDAC inhibitors}

It is well-recognized that VPA has a range of pharmacological properties, including HDAC inhibition (HDACi). We examined whether other HDAC compounds have similar gene expression signatures as VPA and which specific HDAC isoform contributes to gene regulation. In the first nCounter® experiments, VPA-regulated genes $M M P 13, V G F$ and $Z C C H C 12$ showed differential expression when exposed to TSA, thus implying HDAC inhibition might be important in regulation of these genes. VPA is a major class I HDACi [1] therefore, in the second nCounter ${ }^{\circledR}$ run, selective HDAC 1, 3 and 8 inhibitors were used. Gene expression changes in response to VPA, VPD (a non-HDACi analogue of VPA) and other HDAC inhibitors were compared, and genes observed in both runs, with either or both analyses, were considered to be reproducible and of high confidence.

Comparing DEG between VPA and VPD exposures, MMP13 and SERPINB2 were downregulated by VPD but upregulated by VPA. For HDAC inhibitors, changes were only observed with TSA and CI994 (HDAC 1 inhibitor). TSA upregulated MMP13 and VGF, and downregulated ZCCHC12. CI994 upregulated MAOB, NGFR, WNT6 and ZCCHC12. Notably, the direction of change differed between these two drugs for ZCCHC12; VPA and CI994 upregulated ZCCHC12 whereas TSA downregulated it.

This study revealed important insights into the mechanism of action of VPA. Comparing gene expression with VPA, other HDACs and a non-HDACi analogue of VPA shows that the pattern of DEGs regulated by VPA is probably a sum of its different mechanisms of action. VPA-regulated DEGs are only partly shared with another HDAC inhibitor or VPD. Our findings therefore suggest that VPA may have multiple mechanisms of action, with both its HDACi and other properties being important.

No change in gene expression was observed with HDAC3 (RGFP966) and HDAC8 inhibitors (PCI34051), which suggested that the HDAC3 and HDAC8 inhibitory activity of VPA was not relevant to the gene expression effects observed in this RN46A assay system. These results suggested inhibition of HDAC1 was most relevant to gene regulation in RN46A cells.

In addition, HDAC6 was shown to be upregulated by VPA, in RN46A cells, in a prior qPCR study from our laboratory [109] therefore, the effect of HDAC6 inhibition was examined on the VPA-regulated genes. However, our analysis showed tubastatin A (an HDAC6 inhibitor) treatment did not affect any of the selected VPA-regulated genes.

It has been speculated that VPA regulates mood through its non-histone targets and HDACi is responsible for its antitumor properties $[110,111]$. However, HDAC inhibitors have been shown to have antimanic effects $[112,113]$. VPA, SAHA and MS-275 can normalize mania-like behaviour in the CLOCK $\triangle 19$ mouse model [114]. Increased HDAC activity in prefrontal cortex is seen in mania rodent models which can be partially reversed with lithium, VPA and sodium butyrate [115]. VPA DEGs from 
our study, both HDAC inhibited and non-HDAC regulated, have neuronal functions and are implicated in mood disorders. This suggests that genes altered by VPA are important to mood biology, irrespective of their mechanism of regulation.

\section{Acknowledgement}

This work was supported by the Jim and Mary Carney Charitable Trust, Whangarei, New Zealand, including a Postgraduate Scholarship from this source.

\section{Conflict of interest}

None of the authors report any competing financial interests or other conflicts of interest in relation to this work. The RN46A cell line was a kind gift from Dr Scott Whittemore, Laboratory of Molecular Neurobiology, Louisville, Kentucky, USA.

Supplementary information is available at the Pharmacogenomics Journal's website.

\section{References}

1. Phiel, C.J., et al., Histone deacetylase is a direct target of valproic acid, a potent anticonvulsant, mood stabilizer, and teratogen. J Biol Chem, 2001. 276(39): p. 36734-41.

2. Gottlicher, M., et al., Valproic acid defines a novel class of HDAC inhibitors inducing differentiation of transformed cells. Embo j, 2001. 20(24): p. 6969-78.

3. Cipriani, A., et al., Valproic acid, valproate and divalproex in the maintenance treatment of bipolar disorder. Cochrane Database Syst Rev, 2013(10): p. CD003196.

4. $\quad$ Sargent, P.A., et al., 5-HT(1A) receptor binding in euthymic bipolar patients using positron emission tomography with [carbonyl-(11)C]WAY-100635. J Affect Disord, 2010. 123(1-3): p. 77-80.

5. Wu, J.B. and J.C. Shih, Valproic acid induces monoamine oxidase A via Akt/FoxO1 activation. Molecular Pharmacology, 2011. 80(4): p. 714-723.

6. Chen, P.S., et al., Valproate protects dopaminergic neurons in midbrain neuron/glia cultures by stimulating the release of neurotrophic factors from astrocytes. Mol Psychiatry, 2006. 11(12): p. 1116-25.

7. Rosenberg, G., The mechanisms of action of valproate in neuropsychiatric disorders: can we see the forest for the trees? Cell Mol Life Sci, 2007. 64(16): p. 2090-103.

8. Chiu, C.T., et al., Therapeutic potential of mood stabilizers lithium and valproic acid: beyond bipolar disorder. Pharmacol Rev, 2013. 65(1): p. 105-42.

9. Soeiro-de-Souza, Márcio G., et al., Anterior cingulate Glutamate-Glutamine cycle metabolites are altered in euthymic bipolar I disorder. European Neuropsychopharmacology, 2015. 25(12): p. 2221-2229.

10. Soeiro-de-Souza, M.G., et al., Anterior Cingulate Cortex Glutamatergic Metabolites and Mood Stabilizers in Euthymic Bipolar I Disorder Patients: A Proton Magnetic Resonance Spectroscopy Study. Biological Psychiatry: Cognitive Neuroscience and Neuroimaging, 2018.

11. Yu, W., et al., MCK1 is a novel regulator of myo-inositol phosphate synthase (MIPS) that is required for inhibition of inositol synthesis by the mood stabilizer valproate. PloS one, 2017. 12(8): p. $\mathrm{e} 0182534$. 
12. Silverstone, P.H. and B.M. McGrath, Lithium and valproate and their possible effects on themyoinositol second messenger system in healthy volunteers and bipolar patients. International Review of Psychiatry, 2009. 21(4): p. 414-423.

13. Hashimoto, K., et al., Valproate Inhibits Methamphetamine Induced Hyperactivity via Glycogen Synthase Kinase 3 $\beta$ Signaling in the Nucleus Accumbens Core. Plos One, 2015. 10(6): p. e0128068.

14. Abrial, E., et al., Protein kinase $C$ regulates mood-related behaviors and adult hippocampal cell proliferation in rats. Progress in neuro-psychopharmacology \& biological psychiatry, 2013. 43: p. 40-8.

15. Ludtmann, M.H., K. Boeckeler, and R.S. Williams, Molecular pharmacology in a simple model system: implicating MAP kinase and phosphoinositide signalling in bipolar disorder. Semin Cell Dev Biol, 2011. 22(1): p. 105-13.

16. Einat, H., et al., Possible involvement of the ERK signaling cascade in bipolar disorder: behavioral leads from the study of mutant mice. Drug News Perspect, 2003. 16(7): p. 453-63.

17. Maletic, V. and C. Raison, Integrated neurobiology of bipolar disorder. Front Psychiatry, 2014. 5: p. 98.

18. Shiah, I.S. and L.N. Yatham, Serotonin in mania and in the mechanism of action of mood stabilizers: a review of clinical studies. Bipolar Disord, 2000. 2(2): p. 77-92.

19. $\mathrm{Yu}, \mathrm{W}$. and M.L. Greenberg, Inositol depletion, GSK3 inhibition and bipolar disorder. Future Neurology, 2016. 11(2): p. 135-148.

20. Chen, G., et al., The mood-stabilizing agent valproate inhibits the activity of glycogen synthase kinase-3. J Neurochem, 1999. 72(3): p. 1327-30.

21. Chen, G., et al., Chronic sodium valproate selectively decreases protein kinase $C$ alpha and epsilon in vitro. J Neurochem, 1994. 63(6): p. 2361-4.

22. Chen, G., et al., Effects of valproic acid on beta-adrenergic receptors, G-proteins, and adenylyl cyclase in rat C6 glioma cells. Neuropsychopharmacology, 1996. 15(3): p. 271-80.

23. Chen, G., et al., Increase in AP-1 transcription factor DNA binding activity by valproic acid. Neuropsychopharmacology, 1997. 16(3): p. 238-45.

24. Chen, G., et al., Valproate robustly enhances AP-1 mediated gene expression. Brain Res Mol Brain Res, 1999. 64(1): p. 52-8.

25. Daniel, E.D., A.W. Mudge, and P.R. Maycox, Comparative analysis of the effects of four mood stabilizers in SH-SY5Y cells and in primary neurons. Bipolar Disorders, 2005. 7(1): p. 33-41.

26. Adams, L.J. and P.R. Schofield, Microarray studies of changes in gene expression in mouse brain induced by anti-manic drugs. American Journal of Medical Genetics - Neuropsychiatric Genetics, 2001. 105(7): p. 582-583.

27. Bosetti, F., J.M. Bell, and P. Manickam, Microarray analysis of rat brain gene expression after chronic administration of sodium valproate. Brain Research Bulletin, 2005. 65(4): p. 331-338.

28. Chetcuti, A., et al., Altered gene expression in mice treated with the mood stabilizer sodium valproate. Int J Neuropsychopharmacol, 2006. 9(3): p. 267-76.

29. Fukuchi, M., et al., Valproic acid induces up- or down-regulation of gene expression responsible for the neuronal excitation and inhibition in rat cortical neurons through its epigenetic actions. Neurosci Res, 2009. 65(1): p. 35-43.

30. LaBonte, M.J., et al., DNA microarray profiling of genes differentially regulated by the histone deacetylase inhibitors vorinostat and LBH589 in colon cancer cell lines. BMC Med Genomics, 2009. 2: p. 67.

31. Zhang, X.-Z., et al., Using an exon microarray to identify a global profile of gene expression and alternative splicing in K562 cells exposed to sodium valproate. Oncology Reports, 2012. 27(4): p. 1258-1265.

32. Lee, R.S., et al., Search for common targets of lithium and valproic acid identifies novel epigenetic effects of lithium on the rat leptin receptor gene. Transl Psychiatry, 2015. 5: p. e600. 
33. Jornada, L.K., et al., Effects of mood stabilizers on hippocampus and amygdala BDNF levels in an animal model of mania induced by ouabain. Journal of Psychiatric Research, 2010. 44(8): p. 506510 .

34. Chang, Y.C., S.I. Rapoport, and J.S. Rao, Chronic Administration of Mood Stabilizers Upregulates BDNF and Bcl-2 Expression Levels in Rat Frontal Cortex. Neurochemical Research, 2009. 34(3): p. 536-541.

35. Asghari, V., et al., Differential effects of mood stabilizers on Fos/Jun proteins and AP-1 DNA binding activity in human neuroblastoma SH-SY5Y cells. Brain Res Mol Brain Res, 1998. 58(1-2): p. 95102.

36. Herteleer, L., et al., Mood stabilizing drugs regulate transcription of immune, neuronal and metabolic pathway genes in Drosophila. Psychopharmacology, 2016. 233(9): p. 1751-1762.

37. Hornung, J.P., The human raphe nuclei and the serotonergic system. J Chem Neuroanat, 2003. 26(4): p. 331-43.

38. White, L.A., et al., Distinct regulatory pathways control neurofilament expression and neurotransmitter synthesis in immortalized serotonergic neurons. J Neurosci, 1994. 14(11 Pt 1): p. 6744-53.

39. McHugh, P.C., P.R. Joyce, and M.A. Kennedy, Polymorphisms of sepiapterin reductase gene alter promoter activity and may influence risk of bipolar disorder. Pharmacogenetics and Genomics, 2009. 19(5): p. 330-337.

40. McHugh, P.C., et al., A polymorphism of the GTP-cyclohydrolase I feedback regulator gene alters transcriptional activity and may affect response to SSRI antidepressants. The Pharmacogenomics Journal, 2010. 11(3): p. 207-213.

41. Balasubramanian, D., J.F. Pearson, and M.A. Kennedy, Gene expression effects of lithium and valproic acid in a serotonergic cell line. Physiological Genomics, 2019. 51(2): p. 43-50.

42. Glubb, D.M., P.R. Joyce, and M.A. Kennedy, Expression and association analyses of promoter variants of the neurogenic gene HES6, a candidate gene for mood disorder susceptibility and antidepressant response. Neuroscience Letters, 2009. 460(2): p. 185-190.

43. Glubb, D.M., et al., Association of a functional polymorphism in the adrenomedullin gene (ADM) with response to paroxetine. Pharmacogenomics J, 2010. 10(2): p. 126-33.

44. Balasubramanian, D., et al., Valproic acid exposure leads to upregulation and increased promoter histone acetylation of sepiapterin reductase in a serotonergic cell line. Neuropharmacology, 2015. 99: p. 79-88.

45. Eaton, M.J., et al., Developmental regulation of early serotonergic neuronal differentiation: the role of brain-derived neurotrophic factor and membrane depolarization. Dev Biol, 1995. 170(1): p. 169-82.

46. Fleming, J. and M. Chetty, Therapeutic Monitoring of Valproate in Psychiatry. Clinical Neuropharmacology, 2006. 29(6): p. 350-360.

47. Severus, W.E., et al., What is the optimal serum lithium level in the long-term treatment of bipolar disorder--a review? Bipolar Disord, 2008. 10(2): p. 231-7.

48. Reddy, D.S. and M.S. Reddy, Serum Lithium Levels: Ideal Time for Sample Collection! Are We Doing it Right? Indian J Psychol Med, 2014. 36(3): p. 346-7.

49. Chalecka-Franaszek, E. and D.M. Chuang, Lithium activates the serine/threonine kinase Akt-1 and suppresses glutamate-induced inhibition of Akt-1 activity in neurons. Proceedings of the National Academy of Sciences of the United States of America, 1999. 96(15): p. 8745-50.

50. Lai, J.S., et al., Cytoprotection by lithium and valproate varies between cell types and cellular stresses. European journal of pharmacology, 2006. 539(1-2): p. 18-26.

51. Shao, L., L.T. Young, and J.F. Wang, Chronic treatment with mood stabilizers lithium and valproate prevents excitotoxicity by inhibiting oxidative stress in rat cerebral cortical cells. Biol Psychiatry, 2005. 58(11): p. 879-84.

52. Nciri, R., et al., Chronic neuroprotective effects of low concentration lithium on SH-SY5Y cells: possible involvement of stress proteins and gene expression. Neural Regen Res, 2014. 9(7): p. 735-40. 
53. Kim, H.J. and S.A. Thayer, Lithium increases synapse formation between hippocampal neurons by depleting phosphoinositides. Mol Pharmacol, 2009. 75(5): p. 1021-30.

54. O'Donnell, T., et al., Chronic lithium and sodium valproate both decrease the concentration of myoinositol and increase the concentration of inositol monophosphates in rat brain. Brain Research, 2000. 880(1-2): p. 84-91.

55. Otero Losada, M.E. and M.C. Rubio, Acute and chronic effects of lithium chloride on GABA-ergic function in the rat corpus striatum and frontal cerebral cortex. Naunyn Schmiedebergs Arch Pharmacol, 1986. 332(2): p. 169-72.

56. Fukumoto, T., et al., Chronic lithium treatment increases the expression of brain-derived neurotrophic factor in the rat brain. Psychopharmacology, 2001. 158(1): p. 100-106.

57. Hillert, M., M. Zimmermann, and J. Klein, Uptake of lithium into rat brain after acute and chronic administration. Neurosci Lett, 2012. 521(1): p. 62-6.

58. Dobin, A., et al., STAR: ultrafast universal RNA-seq aligner. Bioinformatics, 2013. 29(1): p. 15-21.

59. Bray, N.L., et al., Near-optimal probabilistic RNA-seq quantification. Nature Biotechnology, 2016. 34(5): p. 525-527.

60. Patro, R., et al., Salmon provides fast and bias-aware quantification of transcript expression. Nat Methods, 2017. 14(4): p. 417-419.

61. Love, M.I., W. Huber, and S. Anders, Moderated estimation of fold change and dispersion for RNAseq data with DESeq2. Genome Biol, 2014. 15(12): p. 550.

62. Trapnell, C., et al., Differential analysis of gene regulation at transcript resolution with RNA-seq. Nature Biotechnology, 2012. 31(1): p. 46-53.

63. Trapnell, C., et al., Transcript assembly and quantification by RNA-Seq reveals unannotated transcripts and isoform switching during cell differentiation. Nature Biotechnology, 2010. 28(5): p. 511-515.

64. Ge, S.X., E.W. Son, and R. Yao, iDEP: an integrated web application for differential expression and pathway analysis of RNA-Seq data. BMC Bioinformatics, 2018. 19(1).

65. Robinson, M.D., D.J. McCarthy, and G.K. Smyth, edgeR: a Bioconductor package for differential expression analysis of digital gene expression data. Bioinformatics, 2010. 26(1): p. 139-40.

66. Wang, H., et al., NanoStringDiff: a novel statistical method for differential expression analysis based on NanoString $n$ Counter data. Nucleic Acids Research, 2016: p. gkw677.

67. Benjamini, Y. and Y. Hochberg, Controlling the False Discovery Rate: A Practical and Powerful Approach to Multiple Testing. Journal of the Royal Statistical Society. Series B (Methodological), 1995. 57(1): p. 289-300.

68. Carithers, L.J., et al., A Novel Approach to High-Quality Postmortem Tissue Procurement: The GTEx Project. Biopreserv Biobank, 2015. 13(5): p. 311-9.

69. Sunkin, S.M., et al., Allen Brain Atlas: an integrated spatio-temporal portal for exploring the central nervous system. Nucleic Acids Research, 2012. 41(D1): p. D996-D1008.

70. Adell, A., Revisiting the role of raphe and serotonin in neuropsychiatric disorders. The Journal of General Physiology, 2015. 145(4): p. 257-259.

71. Ornoy, A., Valproic acid in pregnancy: How much are we endangering the embryo and fetus? Reproductive Toxicology, 2009. 28(1): p. 1-10.

72. Wieck, A. and S. Jones, Dangers of valproate in pregnancy. Bmj, 2018: p. k1609.

73. Tobe, B.T.D., et al., Probing the lithium-response pathway in hiPSCs implicates the phosphoregulatory set-point for a cytoskeletal modulator in bipolar pathogenesis. Proc Natl Acad Sci U S A, 2017. 114(22): p. E4462-E4471.

74. Cruceanu, C., et al., Synapsin II is involved in the molecular pathway of lithium treatment in bipolar disorder. PLoS One, 2012. 7(2): p. e32680.

75. Hill, A.S., et al., Increasing Adult Hippocampal Neurogenesis is Sufficient to Reduce Anxiety and Depression-Like Behaviors. Neuropsychopharmacology, 2015. 40(10): p. 2368-2378.

76. Schloesser, R.J., et al., Antidepressant-like Effects of Electroconvulsive Seizures Require Adult Neurogenesis in a Neuroendocrine Model of Depression. Brain Stimul, 2015. 8(5): p. 862-7. 
77. Malberg, J.E., et al., Chronic antidepressant treatment increases neurogenesis in adult rat hippocampus. J Neurosci, 2000. 20(24): p. 9104-10.

78. Santarelli, L., et al., Requirement of hippocampal neurogenesis for the behavioral effects of antidepressants. Science, 2003. 301(5634): p. 805-9.

79. Castrén, E. and R. Hen, Neuronal plasticity and antidepressant actions. Trends in Neurosciences, 2013. 36(5): p. 259-267.

80. Fornito, A., et al., In vivo evidence for early neurodevelopmental anomaly of the anterior cingulate cortex in bipolar disorder. Acta psychiatrica Scandinavica, 2007. 116(6): p. 467-72.

81. Schloesser, R.J., G. Chen, and H.K. Manji, Neurogenesis and neuroenhancement in the pathophysiology and treatment of bipolar disorder. Int Rev Neurobiol, 2007. 77: p. 143-78.

82. Schloesser, R.J., K. Martinowich, and H.K. Manji, Mood-stabilizing drugs: mechanisms of action. Trends Neurosci, 2012. 35(1): p. 36-46.

83. Hajek, T., et al., Hippocampal volumes in bipolar disorders: opposing effects of illness burden and lithium treatment. Bipolar Disord, 2012. 14(3): p. 261-70.

84. Jang, S. and H.-S. Jeong, Histone deacetylase inhibition-mediated neuronal differentiation via the Wnt signaling pathway in human adipose tissue-derived mesenchymal stem cells. Neuroscience Letters, 2018. 668: p. 24-30.

85. Jacob, J., et al., Valproic acid silencing of ascl1b/Ascl1 results in the failure of serotonergic differentiation in a zebrafish model of fetal valproate syndrome. Dis Model Mech, 2014. 7(1): p. 10717.

86. Yu, I.T., et al., Valproic acid promotes neuronal differentiation by induction of proneural factors in association with H4 acetylation. Neuropharmacology, 2009. 56(2): p. 473-480.

87. Hall, A.C., et al., Valproate regulates GSK-3-mediated axonal remodeling and synapsin I clustering in developing neurons. Mol Cell Neurosci, 2002. 20(2): p. 257-70.

88. Xiao, Y., et al., The DNA methylome and transcriptome of different brain regions in schizophrenia and bipolar disorder. PLoS One, 2014. 9(4): p. e95875.

89. Subramanian, A., et al., Gene set enrichment analysis: A knowledge-based approach for interpreting genome-wide expression profiles. Proceedings of the National Academy of Sciences, 2005. 102(43): p. 15545-15550.

90. Lubbers, B.R., et al., Neural ECM in addiction, schizophrenia, and mood disorder. 2014. 214: p. 263284.

91. Pantazopoulos, H. and S. Berretta, In Sickness and in Health: Perineuronal Nets and Synaptic Plasticity in Psychiatric Disorders. Neural Plast, 2016. 2016: p. 9847696.

92. Drago, A., et al., Genetic Variations within Metalloproteinases Impact on the Prophylaxis of Depressive Phases in Bipolar Patients. Neuropsychobiology, 2014. 69(2): p. 76-82.

93. Berretta, S., Extracellular matrix abnormalities in schizophrenia. Neuropharmacology, 2012. 62(3): p. 1584-1597.

94. Gupta, A., et al., Interaction networks of lithium and valproate molecular targets reveal a striking enrichment of apoptosis functional clusters and neurotrophin signaling. Pharmacogenomics J, 2012. 12(4): p. 328-41.

95. Gurvich, N. and P.S. Klein, Lithium and valproic acid: Parallels and contrasts in diverse signaling contexts. Pharmacology and Therapeutics, 2002. 96(1): p. 45-66.

96. Valvassori, S.S., et al., Lithium and valproate act on the GSK-3beta signaling pathway to reverse manic-like behavior in an animal model of mania induced by ouabain. Neuropharmacology, 2017. 117: p. 447-459.

97. Van de Pette, M., et al., Visualizing Changes in Cdkn1c Expression Links Early-Life Adversity to Imprint Mis-regulation in Adults. Cell Reports, 2017. 18(5): p. 1090-1099.

98. Furutachi, S., et al., p57 controls adult neural stem cell quiescence and modulates the pace of lifelong neurogenesis. EMBO J, 2013. 32(7): p. 970-81.

99. Brietzke, E., et al., Comparison of cytokine levels in depressed, manic and euthymic patients with bipolar disorder. Journal of Affective Disorders, 2009. 116(3): p. 214-217. 
100. Modabbernia, A., et al., Cytokine Alterations in Bipolar Disorder: A Meta-Analysis of 30 Studies. Biological Psychiatry, 2013. 74(1): p. 15-25.

101. Kunz, M., et al., Serum levels of IL-6, IL-10 and TNF-alpha in patients with bipolar disorder and schizophrenia: differences in pro- and anti-inflammatory balance. Rev Bras Psiquiatr, 2011. 33(3): p. 268-74.

102. Barbosa, I.G., et al., The immunology of bipolar disorder. Neuroimmunomodulation, 2014. 21(23): p. 117-22.

103. Rao, J.S., et al., Increased excitotoxicity and neuroinflammatory markers in postmortem frontal cortex from bipolar disorder patients. Molecular psychiatry, 2010. 15(4): p. 384-92.

104. Zhang, S.J., et al., Nuclear calcium signaling controls expression of a large gene pool: identification of a gene program for acquired neuroprotection induced by synaptic activity. PLoS Genet, 2009. 5(8): p. e1000604.

105. Carlson, P.J., et al., Neural circuitry and neuroplasticity in mood disorders: Insights for novel therapeutic targets. NeuroRx, 2006. 3(1): p. 22-41.

106. Rocha, M.V., et al., Neuroplasticity in Bipolar Disorder: Insights from Neuroimaging. 2017.

107. Boku, S., et al., Valproate recovers the inhibitory effect of dexamethasone on the proliferation of the adult dentate gyrus-derived neural precursor cells via GSK-3beta and beta-catenin pathway. Eur J Pharmacol, 2014. 723: p. 425-30.

108. Wexler, E.M., D.H. Geschwind, and T.D. Palmer, Lithium regulates adult hippocampal progenitor development through canonical Wnt pathway activation. Molecular Psychiatry, 2008. 13(3): p. 285292.

109. Deng, X., Gene Regulation by Drugs Used to Treat Mood Disorders in Pathology. 2011, Univesity of Otago.

110. Gould, T.D., G. Chen, and H.K. Manji, Mood stabilizer psychopharmacology. Clin Neurosci Res, 2002. 2(3-4): p. 193-212.

111. Lagace, D.C., et al., Valproic acid: how it works. Or not. Clinical Neuroscience Research, 2004. 4(3-4): p. 215-225.

112. Arent, C.O., et al., Neuroanatomical profile of antimaniac effects of histone deacetylases inhibitors. Mol Neurobiol, 2011. 43(3): p. 207-14.

113. Machado-Vieira, R., L. Ibrahim, and C.A.Z. Jr, Histone Deacetylases and Mood Disorders: Epigenetic Programming in Gene-Environment Interactions. CNS Neuroscience \& Therapeutics, 2010. 17(6): p. 699-704.

114. Roybal, K., et al., Mania-like behavior induced by disruption of CLOCK. Proceedings of the National Academy of Sciences, 2007. 104(15): p. 6406-6411.

115. Stertz, L., et al., Histone deacetylase activity and brain-derived neurotrophic factor (BDNF) levels in a pharmacological model of mania. Revista Brasileira de Psiquiatria, 2013. 36(1): p. 39-46. 


\section{Figures}

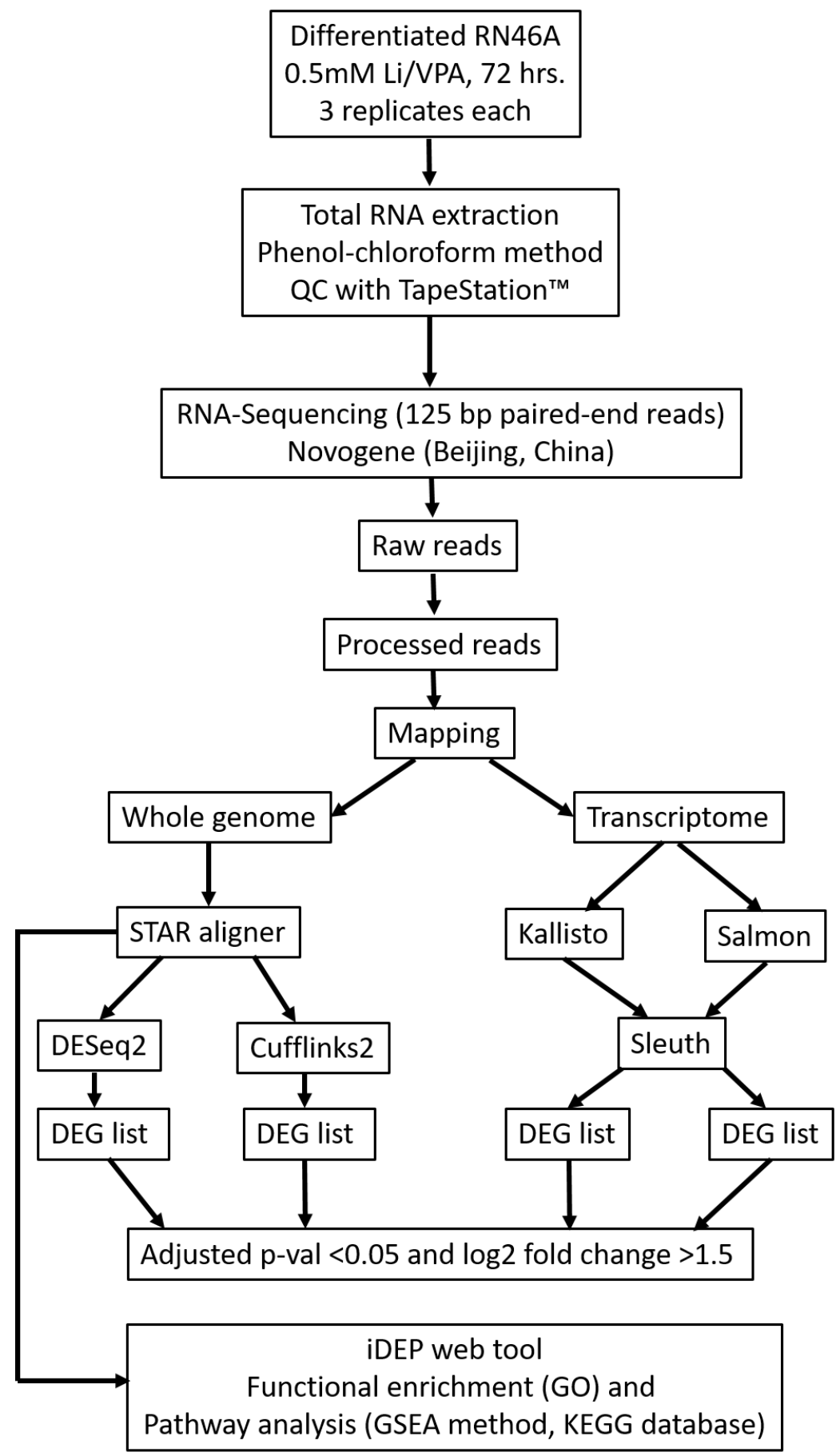

Figure 1. Flowchart of RNA-Seq data analysis procedure. Differential gene expression analysis was performed with DESeq2, cufflinks2 suite and sleuth. Li: lithium, QC: quality control, DEG: differentially expressed genes, iDEP: integrated differential expression and pathway analysis. GSEA: gene set enrichment analysis, KEGG: Kyoto Encyclopedia of Genes and Genomes. 


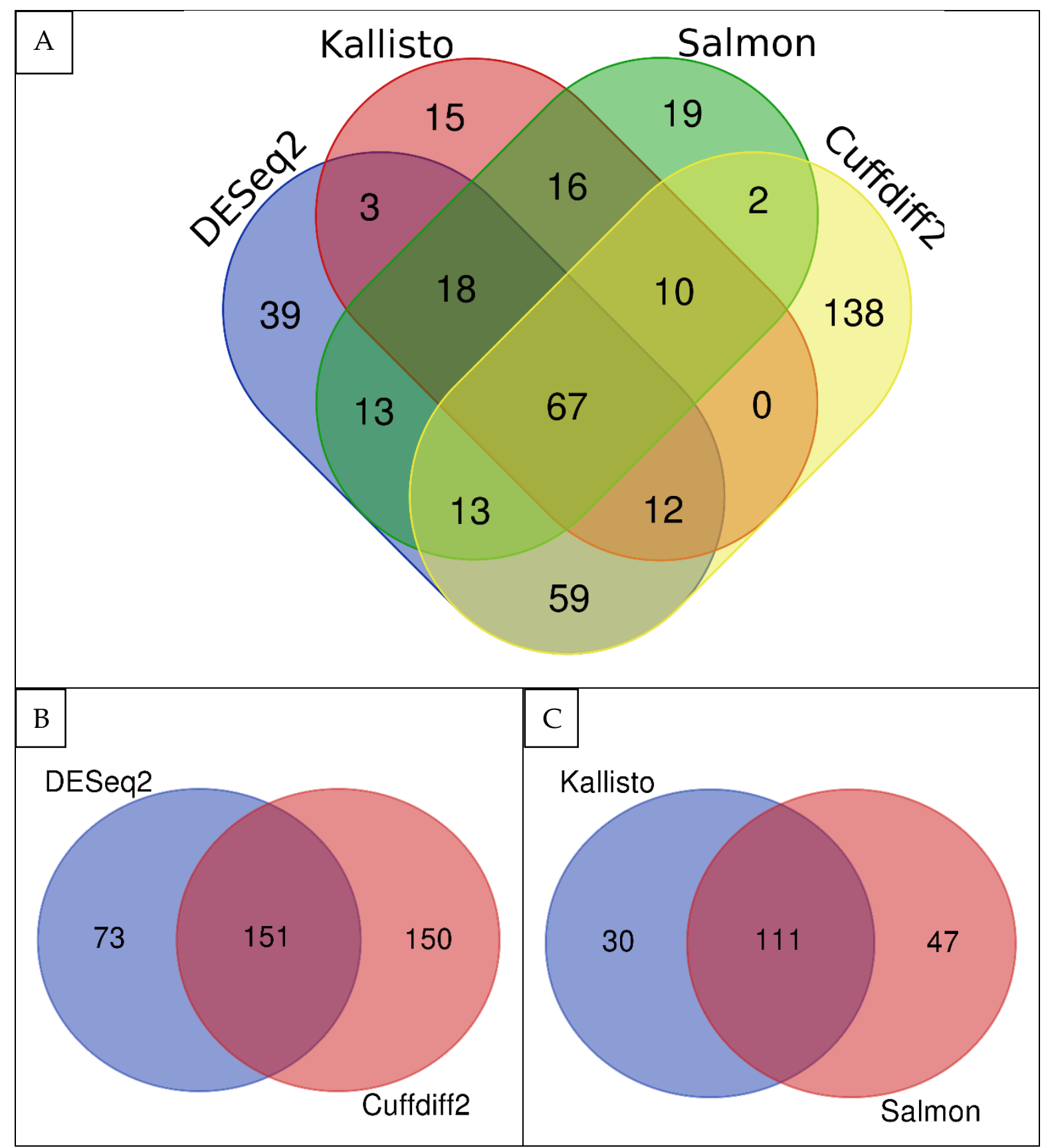

Figure 2. Agreement between the four DEA methods. The panel A shows the four-way comparison of the DEA tools. The panels B and C indicate the two-way comparison to clarify relationships between whole-genome DEA methods (Cuffdiff2 and DESeq2) and transcriptome DEA methods (kallisto and salmon). 


\section{Tables}

Table 1. Top 25 differentially expressed genes in response to VPA as identified with DESeq2.

\begin{tabular}{|c|c|c|c|c|}
\hline Gene name & Base mean control ${ }^{1}$ & Base mean VPA $^{1}$ & $\log 2 \mathrm{FC}$ & padj $^{2}$ \\
\hline IGF2 & $1.78 \pm 0.71$ & $139.77 \pm 17.44$ & 4.15 & $8.40 \mathrm{E}-32$ \\
\hline ADGRB2 & $34.57 \pm 11.33$ & $418.11 \pm 47.94$ & 3.03 & $4.38 \mathrm{E}-28$ \\
\hline$A Q P 1$ & $1813.82 \pm 161.36$ & $349.61 \pm 34.24$ & -2.26 & 7.43E-28 \\
\hline MMP13 & $1066.38 \pm 144.15$ & $6415.40 \pm 855.59$ & 2.39 & $1.22 \mathrm{E}-25$ \\
\hline VGF & $30.11 \pm 17.49$ & $642.32 \pm 161.08$ & 3.34 & 1.07E-24 \\
\hline ZCCHC12 & $60.32 \pm 6.42$ & $443.85 \pm 73.79$ & 2.52 & $1.24 \mathrm{E}-22$ \\
\hline IL20RB & $190.62 \pm 35.73$ & $14.04 \pm 5.16$ & -2.95 & 3.27E-20 \\
\hline NGFR & $47.83 \pm 8.42$ & $327.14 \pm 37.71$ & 2.38 & 1.79E-19 \\
\hline TSPAN13 & $72.98 \pm 8.75$ & $457.96 \pm 87.42$ & 2.33 & $1.86 \mathrm{E}-18$ \\
\hline COL3A1 & $2014.23 \pm 727.89$ & $245.37 \pm 50.45$ & -2.53 & 4.17E-17 \\
\hline LSP1 & $186.31 \pm 12.93$ & $22.84 \pm 8.96$ & -2.61 & 4.63E-17 \\
\hline$A G A P 2$ & $0.25 \pm 0.44$ & $63.11 \pm 9.77$ & 3.31 & $1.34 \mathrm{E}-16$ \\
\hline SNAP91 & $13.02 \pm 3.28$ & $137.50 \pm 10.69$ & 2.63 & $2.18 \mathrm{E}-16$ \\
\hline WNT6 & $30.12 \pm 6.36$ & $227.07 \pm 38.69$ & 2.38 & $8.01 \mathrm{E}-16$ \\
\hline NXPH4 & $3.74 \pm 2.32$ & $79.60 \pm 18.76$ & 2.98 & 8.42E-16 \\
\hline TMEM130 & $19.20 \pm 5.1$ & $162.75 \pm 26.61$ & 2.47 & $1.55 \mathrm{E}-14$ \\
\hline ADAM23 & $19.14 \pm 8.71$ & $123.74 \pm 24.97$ & 2.55 & $1.91 \mathrm{E}-14$ \\
\hline CLGN & $30.93 \pm 2.57$ & $176.08 \pm 24.33$ & 2.20 & $8.31 \mathrm{E}-14$ \\
\hline$E R B B 3$ & $67.54 \pm 16.86$ & $289.04 \pm 22.42$ & 1.99 & $3.36 \mathrm{E}-13$ \\
\hline RGD1563349 & $5.10 \pm 1.49$ & $67.82 \pm 5.15$ & 2.73 & 7.39E-13 \\
\hline CHRNA5 & $2.48 \pm 1.86$ & $52.68 \pm 6.89$ & 2.86 & $1.30 \mathrm{E}-12$ \\
\hline АТР1B2 & $38.83 \pm 8.26$ & $199.63 \pm 29.11$ & 2.11 & $1.34 \mathrm{E}-12$ \\
\hline TMEFF1 & $1.88 \pm 1.46$ & $53.25 \pm 5.51$ & 2.87 & $1.74 \mathrm{E}-12$ \\
\hline FAM25A & $82.84 \pm 33.0$ & $5.53 \pm 1.74$ & -2.71 & 2.06E-12 \\
\hline PERP & $26.70 \pm 4.62$ & $150.22 \pm 23.25$ & 2.16 & $3.29 \mathrm{E}-12$ \\
\hline
\end{tabular}

${ }^{1}$ Ranked by p-values. Base mean control and base mean VPA refer to the mean of normalized counts from four replicates each of untreated and VPA-treated samples. Fold difference between the untreated (control) samples and samples treated with VPA are shown. 
bioRxiv preprint doi: https://doi.org/10.1101/837732; this version posted November 12, 2019. The copyright holder for this preprint (which was not certified by peer review) is the author/funder, who has granted bioRxiv a license to display the preprint in perpetuity. It is made available under aCC-BY-NC-ND 4.0 International license.

${ }^{2}$ FDR indicates false discovery rates which are essentially $\mathrm{p}$ values adjusted for multiple testing using the Benjamini-Hochberg procedure. padj- adjusted p-value. 
Table 2. Genes showing significant expression difference after VPA exposure (Run1 and Run2)

\begin{tabular}{|c|c|c|c|c|c|c|c|c|c|c|c|c|}
\hline \multirow{3}{*}{ Gene Name } & \multicolumn{6}{|c|}{ Run1 } & \multicolumn{6}{|c|}{ Run2 } \\
\hline & \multirow{2}{*}{$\begin{array}{l}\text { Base mean } \\
\text { Control }^{1}\end{array}$} & \multirow{2}{*}{$\begin{array}{l}\text { Base mean } \\
\text { VPA }^{1}\end{array}$} & \multicolumn{2}{|c|}{ nSolver ${ }^{\mathrm{TM}}$} & \multicolumn{2}{|c|}{ NanoStringDiff } & \multirow{2}{*}{$\begin{array}{l}\text { Base mean } \\
\text { control }^{1}\end{array}$} & \multirow{2}{*}{$\begin{array}{l}\text { Base mean } \\
\text { VPA }^{1}\end{array}$} & \multicolumn{2}{|c|}{ nSolver ${ }^{\mathrm{TM}}$} & \multicolumn{2}{|c|}{ NanoStringDiff } \\
\hline & & & $\log 2 \mathrm{FC}$ & pvalue $^{2}$ & $\log 2 \mathrm{FC}$ & pvalue $^{2}$ & & & $\log 2 \mathrm{FC}$ & pvalue $^{2}$ & $\log 2 \mathrm{FC}$ & pvalue $^{2}$ \\
\hline$A D A M 23$ & $1.31 \pm 0.41$ & $7.14 \pm 1.47$ & 2.47 & $2.0 \mathrm{E}-04$ & 26.47 & $7.5 \mathrm{E}-03$ & $37.50 \pm 15.26$ & $148.26 \pm 27.84$ & 1.66 & $1.6 \mathrm{E}-02$ & 1.76 & 1.3E-05 \\
\hline ADGRB2 & $8.93 \pm 4.76$ & $12.53 \pm 2.23$ & 0.68 & $2.4 \mathrm{E}-01$ & 0.49 & $4.2 \mathrm{E}-01$ & $55.48 \pm 12.95$ & $241.17 \pm 12.21$ & 1.88 & $7.9 \mathrm{E}-03$ & 1.98 & 2.1E-09 \\
\hline CACNA1B & $14.00 \pm 8.04$ & $28.71 \pm 2.44$ & 1.43 & $1.4 \mathrm{E}-01$ & 1.06 & $1.8 \mathrm{E}-02$ & $1.33 \pm 0.25$ & $29.80 \pm 17.19$ & 2.25 & $2.8 \mathrm{E}-02$ & 3.74 & 2.0E-05 \\
\hline CDKN1C & $46.70 \pm 6.01$ & $135.59 \pm 6.73$ & 1.55 & $2.0 \mathrm{E}-04$ & 1.6 & 3.7E-07 & $113.15 \pm 19.3$ & $133.84 \pm 25.09$ & 0.18 & 5.1E-01 & 0.22 & 5.1E-01 \\
\hline CNTN1 & $2.44 \pm 0.97$ & $3.46 \pm 01.9$ & 0.36 & 6.3E-01 & 23.43 & $6.1 \mathrm{E}-01$ & $346.69 \pm 58.78$ & $598.86 \pm 67.27$ & 0.77 & $2.8 \mathrm{E}-02$ & 0.78 & 8.2E-03 \\
\hline ERBB3 & $118.14 \pm 22.07$ & $157.60 \pm 25.59$ & 0.42 & 8.9E-02 & 0.43 & 1.7E-01 & $1.33 \pm 0.25$ & $15.53 \pm 3.41$ & 3.09 & $4.6 \mathrm{E}-02$ & 27.19 & 5.3E-07 \\
\hline GNAI1 & $1.07 \pm 0.11$ & $1.10 \pm 0.15$ & 0.04 & 7.7E-01 & 0.33 & $2.6 \mathrm{E}-01$ & $1.33 \pm 0.25$ & $18.23 \pm 11.98$ & 3.63 & $2.3 \mathrm{E}-02$ & 29.67 & 4.7E-07 \\
\hline IGF2 & $2.66 \pm 1.88$ & $1.19 \pm 0.17$ & -0.83 & $2.4 \mathrm{E}-01$ & 22.17 & $4.8 \mathrm{E}-01$ & $1.33 \pm 0.25$ & $5.91 \pm 3.42$ & 2.62 & 1.7E-01 & 29.59 & $2.8 \mathrm{E}-04$ \\
\hline LINGO1 & $3.38 \pm 1.27$ & $13.86 \pm 2.3$ & 2.17 & 1.1E-02 & 7.18 & $5.6 \mathrm{E}-05$ & $1.33 \pm 0.25$ & $10.72 \pm 11.07$ & 2.27 & $6.6 \mathrm{E}-02$ & 34.66 & $1.6 \mathrm{E}-04$ \\
\hline LSP1 & $167.31 \pm 5.19$ & $87.86 \pm 11.24$ & -0.94 & 2.1E-03 & -0.96 & $1.2 \mathrm{E}-03$ & $698.88 \pm 49.72$ & $286.21 \pm 21.02$ & -1.26 & 3.0E-04 & -1.27 & 4.0E-07 \\
\hline LZTS1 & $1.91 \pm 0.78$ & $1.10 \pm 0.15$ & -0.67 & 1.7E-01 & -23.42 & $3.2 \mathrm{E}-01$ & $1.33 \pm 0.25$ & $12.61 \pm 6.41$ & 3.54 & 3.1E-02 & 23.92 & 5.3E-07 \\
\hline МАOB & $15.09 \pm 3.55$ & $24.15 \pm 2.79$ & 0.72 & 4.1E-02 & 0.84 & $6.1 \mathrm{E}-02$ & $67.00 \pm 11.19$ & $376.47 \pm 23.73$ & 2.27 & $1.5 \mathrm{E}-03$ & 2.35 & 1.1E-14 \\
\hline MMP13 & $2652.46 \pm 964.2$ & $4593.43 \pm 784.9$ & 0.85 & 4.4E-02 & 0.79 & $1.8 \mathrm{E}-02$ & $3312.56 \pm 384.81$ & $5281.11 \pm 300.02$ & 0.68 & $1.4 \mathrm{E}-02$ & 0.67 & 5.7E-03 \\
\hline$M P P 3$ & $27.87 \pm 4.23$ & $78.36 \pm 17.39$ & 1.47 & $7.0 \mathrm{E}-04$ & 1.59 & $9.7 \mathrm{E}-06$ & $3.32 \pm 2.80$ & $23.32 \pm 14.69$ & 1 & $1.1 \mathrm{E}-01$ & 1.63 & $1.2 \mathrm{E}-02$ \\
\hline NGFR & $7.90 \pm 4.97$ & $13.99 \pm 2.31$ & 1.16 & $1.5 \mathrm{E}-01$ & 0.96 & $1.1 \mathrm{E}-01$ & $64.65 \pm 16.67$ & $381.39 \pm 57.17$ & 2.33 & $1.6 \mathrm{E}-03$ & 2.41 & $1.2 \mathrm{E}-11$ \\
\hline NOTCH3 & $3.49 \pm 2.36$ & $6.22 \pm 2.99$ & 1.03 & 2.9E-01 & 21.65 & 1.3E-01 & $27.59 \pm 9.5$ & $118.30 \pm 24.31$ & 1.64 & 7.3E-03 & 1.83 & 7.4E-06 \\
\hline PAK3 & $93.46 \pm 19.31$ & $176.60 \pm 34.48$ & 0.92 & 7.3E-03 & 0.94 & $3.5 \mathrm{E}-03$ & $29.12 \pm 3.11$ & $82.33 \pm 7.39$ & 1.09 & $1.5 \mathrm{E}-02$ & 1.26 & 7.8E-04 \\
\hline SERPIN2B & $12.37 \pm 4.63$ & $22.20 \pm 5.18$ & 0.92 & $6.9 \mathrm{E}-02$ & 0.94 & $5.0 \mathrm{E}-02$ & $1349.53 \pm 67.66$ & $2715.63 \pm 182.07$ & 1 & $5.0 \mathrm{E}-04$ & 1 & 1.1E-05 \\
\hline SHANK3 & $13.88 \pm 7.86$ & $22.50 \pm 4.72$ & 1.26 & 2.9E-01 & 0.73 & $1.2 \mathrm{E}-01$ & $1.33 \pm 0.25$ & $2.18 \pm 1.34$ & 2.11 & $5.9 \mathrm{E}-02$ & 27.37 & $3.5 \mathrm{E}-02$ \\
\hline SNAP91 & $143.26 \pm 9.77$ & $230.51 \pm 11.62$ & 0.69 & 1.0E-04 & 0.7 & 1.3E-02 & $33.98 \pm 11.26$ & $89.24 \pm 16.86$ & 1.07 & $1.8 \mathrm{E}-02$ & 1.2 & $1.9 \mathrm{E}-03$ \\
\hline
\end{tabular}




\begin{tabular}{|c|c|c|c|c|c|c|c|c|c|c|c|c|}
\hline \multirow{3}{*}{ Gene Name } & \multicolumn{6}{|c|}{ Run1 } & \multicolumn{6}{|c|}{ Run2 } \\
\hline & \multirow{2}{*}{$\begin{array}{c}\text { Base mean } \\
\text { Control }^{1}\end{array}$} & \multirow{2}{*}{$\begin{array}{l}\text { Base mean } \\
\text { VPA }^{1}\end{array}$} & \multicolumn{2}{|c|}{ nSolver ${ }^{\mathrm{TM}}$} & \multicolumn{2}{|c|}{ NanoStringDiff } & \multirow{2}{*}{$\begin{array}{l}\text { Base mean } \\
\text { control }^{1}\end{array}$} & \multirow{2}{*}{$\begin{array}{l}\text { Base mean } \\
\text { VPA }^{1}\end{array}$} & \multicolumn{2}{|c|}{ nSolver ${ }^{\mathrm{TM}}$} & \multicolumn{2}{|c|}{ NanoStringDiff } \\
\hline & & & $\log 2 \mathrm{FC}$ & pvalue $^{2}$ & $\log 2 \mathrm{FC}$ & pvalue $^{2}$ & & & $\log 2 \mathrm{FC}$ & pvalue $^{2}$ & $\log 2 \mathrm{FC}$ & pvalue $^{2}$ \\
\hline$V G F$ & $22.73 \pm 6.45$ & $111.87 \pm 33.3$ & 2.3 & $6.0 \mathrm{E}-04$ & 2.44 & $8.4 \mathrm{E}-10$ & $44.57 \pm 33.22$ & $123.27 \pm 47.85$ & 1.31 & $1.2 \mathrm{E}-01$ & 1.28 & $2.5 \mathrm{E}-02$ \\
\hline WNT6 & $1.91 \pm 0.78$ & $5.77 \pm 2.17$ & 1.6 & $2.2 \mathrm{E}-02$ & 24.83 & 7.9E-02 & $26.70 \pm 3.42$ & $149.11 \pm 8.65$ & 1.97 & $2.0 \mathrm{E}-04$ & 2.18 & $1.7 \mathrm{E}-10$ \\
\hline ZCCHC12 & $33.68 \pm 9.89$ & $86.28 \pm 7.44$ & 1.41 & $5.2 \mathrm{E}-03$ & 1.47 & 3.1E-05 & $28.09 \pm 11.78$ & $198.19 \pm 31.0$ & 2.35 & 7.2E-03 & 2.45 & $1.0 \mathrm{E}-09$ \\
\hline
\end{tabular}

${ }^{1}$ Base mean control and base mean VPA refer to the mean of normalized counts from four replicates each of untreated and VPA-treated samples in Run1 and

three replicates each of untreated and VPA-treated samples in Run2. Fold difference between the untreated (control) samples and samples treated with VPA are shown. ${ }^{2}$ Bold values indicate the significant genes with $\mathrm{p}$-val $<0.05$. 
Table 3. Genes showing significant expression difference after lithium exposure (Run1 and Run2).

\begin{tabular}{|c|c|c|c|c|c|c|c|c|c|c|c|c|}
\hline \multirow{3}{*}{ Gene Name } & \multicolumn{6}{|c|}{ Run1 (1.0 mM lithium) } & \multicolumn{6}{|c|}{ Run2 (2.0 mM lithium) } \\
\hline & \multirow{2}{*}{$\begin{array}{l}\text { Base } \\
\text { mean } \\
\text { control }^{1}\end{array}$} & \multirow{2}{*}{$\begin{array}{l}\text { Base } \\
\text { mean } \\
\text { lithium }\end{array}$} & \multicolumn{2}{|c|}{ nSolver ${ }^{\mathrm{TM}}$} & \multicolumn{2}{|c|}{ NanoStringDiff } & \multirow{2}{*}{$\begin{array}{l}\text { Base mean } \\
\text { control }^{1}\end{array}$} & \multirow{2}{*}{$\begin{array}{l}\text { Base mean } \\
\text { lithium }^{1}\end{array}$} & \multicolumn{2}{|c|}{ nSolver ${ }^{\mathrm{TM}}$} & \multicolumn{2}{|c|}{ NanoStringDiff } \\
\hline & & & $\log 2 \mathrm{FC}$ & pvalue $^{2}$ & $\log 2 \mathrm{FC}$ & pvalue $^{2}$ & & & $\log 2 \mathrm{FC}$ & pvalue $^{2}$ & $\log 2 \mathrm{FC}$ & pvalue $^{2}$ \\
\hline CDKN1C & $\begin{array}{l}46.70 \pm \\
6.01\end{array}$ & $\begin{array}{l}75.97 \pm \\
10.25\end{array}$ & 0.7 & $3.7 \mathrm{E}-03$ & 0.71 & $5.47 \mathrm{E}-05$ & $113.15 \pm 19.3$ & $84.00 \pm 20.19$ & -0.4 & $2.5 \mathrm{E}-01$ & -0.4 & $1.8 \mathrm{E}-01$ \\
\hline LSP1 & $\begin{array}{l}167.31 \\
\pm 5.19\end{array}$ & $\begin{array}{l}204.42 \pm \\
19.01\end{array}$ & 0.28 & $2.9 \mathrm{E}-02$ & 0.28 & $3.23 \mathrm{E}-03$ & $698.88 \pm 49.72$ & $480.36 \pm 16.73$ & -0.53 & $7.0 \mathrm{E}-03$ & -0.53 & 4.6E-02 \\
\hline SERPIN2B & $\begin{array}{l}12.37 \pm \\
4.63\end{array}$ & $\begin{array}{l}6.72 \\
\pm 0.76\end{array}$ & -0.77 & $1.0 \mathrm{E}-01$ & -1.85 & $8.78 \mathrm{E}-03$ & $\begin{array}{l}1349.53 \pm \\
67.66\end{array}$ & $\begin{array}{l}2489.91 \pm \\
273.19\end{array}$ & 0.87 & $7.0 \mathrm{E}-03$ & 0.88 & 9.1E-04 \\
\hline WNT6 & $\begin{array}{l}1.91 \pm \\
0.78\end{array}$ & $1.51 \pm 0.43$ & -0.26 & $5.8 \mathrm{E}-01$ & -16.82 & $4.78 \mathrm{E}-01$ & $26.70 \pm 3.42$ & $4.92 \pm 5.37$ & -1.32 & $5.0 \mathrm{E}-02$ & -1.6 & $3.4 \mathrm{E}-04$ \\
\hline$M A O B$ & $\begin{array}{l}15.09 \pm \\
3.55\end{array}$ & $\begin{array}{l}17.81 \\
\pm 4.66\end{array}$ & 0.24 & 4.6E-01 & 0.19 & $6.28 \mathrm{E}-01$ & $67.00 \pm 11.19$ & $106.67 \pm 20.64$ & 0.57 & $6.4 \mathrm{E}-02$ & 0.61 & $4.2 \mathrm{E}-02$ \\
\hline CNTN1 & $\begin{array}{l}2.44 \pm \\
0.97\end{array}$ & $5.09 \pm 2.7$ & 0.95 & 2.1E-01 & 21.75 & $4.36 \mathrm{E}-01$ & $346.69 \pm 58.78$ & $235.92 \pm 28.77$ & -0.52 & $8.0 \mathrm{E}-02$ & -0.54 & $5.0 \mathrm{E}-02$ \\
\hline ADAM23 & $\begin{array}{l}1.31 \pm \\
0.41\end{array}$ & $\begin{array}{l}3.42 \\
\pm 3.58\end{array}$ & 0.77 & 3.9E-01 & -80.18 & $4.26 \mathrm{E}-01$ & $37.50 \pm 15.26$ & $13.43 \pm 4.78$ & -0.86 & $8.9 \mathrm{E}-02$ & -1.1 & $3.2 \mathrm{E}-03$ \\
\hline
\end{tabular}

${ }^{1}$ Base mean control and base mean lithium refer to the mean of normalized counts from four replicates each of untreated and lithium-treated samples in Run1 and three replicates each of untreated and lithium-treated samples in Run2. Fold difference between the untreated (control) samples and samples treated with lithium are shown. ${ }^{2}$ Bold values indicate the significant genes with $p$-val $<0.05$. 
Table 4. nCounter® $\log 2$ fold change and p-values for VPA, VPD and TSA-treated RN46A cells in Run1.

\begin{tabular}{|c|c|c|c|c|c|c|c|c|c|c|c|c|c|c|c|c|}
\hline \multirow{3}{*}{$\begin{array}{l}\text { Gene } \\
\text { Name }\end{array}$} & \multirow{3}{*}{$\begin{array}{c}\text { Base } \\
\text { mean } \\
\text { control }^{1}\end{array}$} & \multirow{3}{*}{$\begin{array}{c}\text { Base } \\
\text { mean } \\
\text { VPA }^{1}\end{array}$} & \multirow{3}{*}{$\begin{array}{l}\text { Base } \\
\text { mean } \\
\text { VPD }^{1}\end{array}$} & \multirow{3}{*}{$\begin{array}{c}\text { Base } \\
\text { mean } \\
\text { TSA }^{1}\end{array}$} & \multicolumn{6}{|c|}{ nSolverTM } & \multicolumn{6}{|c|}{ NanoStringDiff } \\
\hline & & & & & \multicolumn{2}{|c|}{ VPA } & \multicolumn{2}{|c|}{ VPD } & \multicolumn{2}{|c|}{ TSA } & \multicolumn{2}{|c|}{ VPA } & \multicolumn{2}{|c|}{ VPD } & \multicolumn{2}{|c|}{ TSA } \\
\hline & & & & & $\begin{array}{c}\text { Log2 } \\
\text { FC }\end{array}$ & $\begin{array}{c}\text { pval } \\
u^{2}\end{array}$ & $\begin{array}{c}\text { Log2 } \\
\text { FC }\end{array}$ & $\begin{array}{r}\text { pval } \\
\text { ue }^{2}\end{array}$ & $\begin{array}{c}\text { Log2 } \\
\text { FC }\end{array}$ & $\begin{array}{c}\text { pval } \\
u^{2}\end{array}$ & $\begin{array}{c}\text { Log2 } \\
\text { FC }\end{array}$ & $\begin{array}{c}\text { pval } \\
u^{2}\end{array}$ & $\begin{array}{c}\text { Log2 } \\
\text { FC }\end{array}$ & $\begin{array}{r}\text { pval } \\
\text { ue }^{2}\end{array}$ & $\begin{array}{c}\text { Log2 } \\
\text { FC }\end{array}$ & $\begin{array}{r}\text { pval } \\
\text { ue }^{2}\end{array}$ \\
\hline$A D A M 23$ & $\begin{array}{ll}1.31 & \pm \\
0.41 & \end{array}$ & $\begin{array}{l}7.14 \quad \pm \\
1.47\end{array}$ & $\begin{array}{l}3.70 \\
\pm 2.47\end{array}$ & $3.99 \pm 2.0$ & 2.47 & $\begin{array}{l}2.2 \mathrm{E} \\
-04\end{array}$ & 1.12 & $\begin{array}{l}2.0 \mathrm{E} \\
-01\end{array}$ & 1.38 & $\begin{array}{l}9.9 \mathrm{E} \\
-02\end{array}$ & $\begin{array}{l}26.4 \\
7\end{array}$ & $\begin{array}{l}7.5 \mathrm{E} \\
-03\end{array}$ & 0.91 & $\begin{array}{l}4.9 \mathrm{E} \\
-01\end{array}$ & $\begin{array}{l}55.4 \\
1\end{array}$ & $\begin{array}{l}5.5 \mathrm{E} \\
-01\end{array}$ \\
\hline ADGRB2 & $\begin{array}{ll}8.93 & \pm \\
4.76 & \end{array}$ & $\begin{array}{ll}12.53 \quad \pm \\
2.23\end{array}$ & $\begin{array}{l}11.13 \\
\pm 1.98\end{array}$ & $\begin{array}{l}12.26 \\
\pm 4.99\end{array}$ & 0.68 & $\begin{array}{l}2.4 \mathrm{E} \\
-01\end{array}$ & 0.51 & $\begin{array}{l}3.6 \mathrm{E} \\
-01\end{array}$ & 0.52 & $\begin{array}{l}4.3 \mathrm{E} \\
-01\end{array}$ & 0.49 & $\begin{array}{l}4.2 \mathrm{E} \\
-01\end{array}$ & 0.07 & $\begin{array}{l}9.1 \mathrm{E} \\
-01\end{array}$ & 0.16 & $\begin{array}{l}7.7 \mathrm{E} \\
-01\end{array}$ \\
\hline CACNA1B & $\begin{array}{l}14.00 \quad \pm \\
8.04\end{array}$ & $\begin{array}{ll}28.71 \quad \pm \\
2.44\end{array}$ & $\begin{array}{r}24.17 \\
\pm 5.48\end{array}$ & $\begin{array}{l}11.71 \\
\pm 4.77\end{array}$ & 1.43 & $\begin{array}{l}1.4 \mathrm{E} \\
-01\end{array}$ & 1.15 & $\begin{array}{l}2.0 \mathrm{E} \\
-01\end{array}$ & 0.04 & $\begin{array}{l}9.6 \mathrm{E} \\
-01\end{array}$ & 1.06 & $\begin{array}{l}1.8 \mathrm{E} \\
-02\end{array}$ & 0.68 & $\begin{array}{l}6.3 \mathrm{E} \\
-02\end{array}$ & -0.81 & $\begin{array}{l}7.7 \mathrm{E} \\
-02\end{array}$ \\
\hline CDKN1C & $\begin{array}{ll}46.70 \quad \pm \\
6.01 & \end{array}$ & $\begin{array}{l}135.59 \pm \\
6.73\end{array}$ & $\begin{array}{l}81.56 \\
\pm 8.05\end{array}$ & $\begin{array}{l}58.12 \\
\pm 11.13\end{array}$ & 1.55 & $\begin{array}{l}1.5 \mathrm{E} \\
-04\end{array}$ & \begin{tabular}{|l|}
0.81 \\
\end{tabular} & $\begin{array}{l}9.8 \mathrm{E} \\
-04\end{array}$ & 0.3 & $\begin{array}{l}1.7 \mathrm{E} \\
-01\end{array}$ & 1.6 & $\begin{array}{l}3.7 E \\
-07\end{array}$ & \begin{tabular}{|l|}
0.8 \\
\end{tabular} & $\begin{array}{l}3.5 \mathrm{E} \\
-05\end{array}$ & 0.29 & $\begin{array}{l}1.8 \mathrm{E} \\
-01\end{array}$ \\
\hline CNTN1 & $\begin{array}{ll}2.44 & \pm \\
0.97 & \end{array}$ & $\begin{array}{l}3.46 \\
\pm 01.9\end{array}$ & $\begin{array}{l}4.49 \\
\pm 3.31\end{array}$ & $3.05 \pm 1.31$ & 0.36 & $\begin{array}{l}6.3 \mathrm{E} \\
-01\end{array}$ & 0.49 & $\begin{array}{l}6.0 \mathrm{E} \\
-01\end{array}$ & 0.29 & $\begin{array}{l}6.6 \mathrm{E} \\
-01\end{array}$ & $\begin{array}{l}23.4 \\
3\end{array}$ & $\begin{array}{l}6.1 \mathrm{E} \\
-01\end{array}$ & \begin{tabular}{|l|}
- \\
15.9 \\
8
\end{tabular} & $\begin{array}{l}6.0 \mathrm{E} \\
-01\end{array}$ & $\begin{array}{l}7.5 \\
2\end{array}$ & $\begin{array}{l}6.0 \mathrm{E} \\
-01\end{array}$ \\
\hline ERBB3 & $\begin{array}{l}118.14 \quad \pm \\
22.07\end{array}$ & $\begin{array}{l}157.60 \quad \pm \\
25.59\end{array}$ & $\begin{array}{r}110.57 \\
\pm 20.89\end{array}$ & $\begin{array}{l}111.06 \\
\pm 8.82\end{array}$ & 0.42 & $\begin{array}{l}8.9 \mathrm{E} \\
-02\end{array}$ & -0.09 & $\begin{array}{l}6.9 \mathrm{E} \\
-01\end{array}$ & -0.07 & $\begin{array}{l}7.2 \mathrm{E} \\
-01\end{array}$ & 0.43 & $\begin{array}{l}1.7 \mathrm{E} \\
-01\end{array}$ & \begin{tabular}{|l|}
-0.09 \\
\end{tabular} & $\begin{array}{l}6.3 \mathrm{E} \\
-01\end{array}$ & \begin{tabular}{|l|}
-0.09 \\
\end{tabular} & $\begin{array}{l}6.0 \mathrm{E} \\
-01\end{array}$ \\
\hline GNAII & $\begin{array}{ll}1.07 & \pm \\
0.11 & \end{array}$ & $\begin{array}{l}1.10 \\
0.15\end{array}$ & $\begin{array}{l}1.29 \\
\pm 0.26\end{array}$ & $1.06 \pm 0.06$ & 0.04 & $\begin{array}{l}7.7 \mathrm{E} \\
-01\end{array}$ & 0.26 & $\begin{array}{l}2.3 \mathrm{E} \\
-01\end{array}$ & 0 & $\begin{array}{l}9.8 \mathrm{E} \\
-01\end{array}$ & 0.33 & $\begin{array}{l}2.6 \mathrm{E} \\
-01\end{array}$ & 3.7 & $\begin{array}{l}2.5 \mathrm{E} \\
-01\end{array}$ & 0.33 & \begin{tabular}{|l}
$2.6 \mathrm{E}$ \\
-01
\end{tabular} \\
\hline$I G F 2$ & $\begin{array}{ll}2.66 & \pm \\
1.88 & \end{array}$ & $\begin{array}{ll}1.19 & \pm \\
0.17 & \end{array}$ & $\begin{array}{l}1.64 \\
\pm 0.75\end{array}$ & $7.27 \pm 6.29$ & -0.83 & \begin{tabular}{|l|}
$2.4 \mathrm{E}$ \\
-01
\end{tabular} & -0.49 & $\begin{array}{l}5.0 \mathrm{E} \\
-01\end{array}$ & 0.82 & $\begin{array}{l}5.4 \mathrm{E} \\
-01\end{array}$ & $\begin{array}{l}22.1 \\
7\end{array}$ & $\begin{array}{l}.8 \mathrm{E} \\
-01\end{array}$ & 2.48 & $\begin{array}{l}4.4 \mathrm{E} \\
-01\end{array}$ & \begin{tabular}{|l|}
26.8 \\
5
\end{tabular} & $\begin{array}{l}6.3 \mathrm{E} \\
-01\end{array}$ \\
\hline
\end{tabular}




\begin{tabular}{|c|c|c|c|c|c|c|c|c|c|c|c|c|c|c|c|c|}
\hline \multirow{3}{*}{$\begin{array}{l}\text { Gene } \\
\text { Name }\end{array}$} & \multirow{3}{*}{$\begin{array}{c}\text { Base } \\
\text { mean } \\
\text { control }^{1}\end{array}$} & \multirow{3}{*}{$\begin{array}{l}\text { Base } \\
\text { mean } \\
\text { VPA }^{1}\end{array}$} & \multirow{3}{*}{$\begin{array}{l}\text { Base } \\
\text { mean } \\
\text { VPD }^{1}\end{array}$} & \multirow{3}{*}{$\begin{array}{c}\text { Base } \\
\text { mean } \\
\text { TSA }^{1}\end{array}$} & \multicolumn{6}{|c|}{ nSolver } & \multicolumn{6}{|c|}{ NanoStringDiff } \\
\hline & & & & & \multicolumn{2}{|c|}{ VPA } & \multicolumn{2}{|c|}{ VPD } & \multicolumn{2}{|c|}{ TSA } & \multicolumn{2}{|c|}{ VPA } & \multicolumn{2}{|c|}{ VPD } & \multicolumn{2}{|c|}{ TSA } \\
\hline & & & & & $\begin{array}{c}\log 2 \\
\text { FC }\end{array}$ & $\begin{array}{r}\text { pval } \\
u^{2}\end{array}$ & $\begin{array}{c}\log 2 \\
\text { FC }\end{array}$ & $\begin{array}{c}\text { pval } \\
\text { ue }^{2}\end{array}$ & $\begin{array}{c}\log 2 \\
\text { FC }\end{array}$ & $\begin{array}{r}\text { pval } \\
u^{2}\end{array}$ & $\begin{array}{r}\log 2 \\
\text { FC }\end{array}$ & $\begin{array}{r}\text { pval } \\
u^{2}\end{array}$ & $\begin{array}{c}\text { Log2 } \\
\text { FC }\end{array}$ & $\begin{array}{c}\text { pval } \\
\text { ue }^{2}\end{array}$ & $\begin{array}{c}\text { Log2 } \\
\text { FC }\end{array}$ & $\begin{array}{r}\text { pval } \\
\text { ue }^{2}\end{array}$ \\
\hline LINGO1 & $\begin{array}{ll}3.38 & \pm \\
1.27 & \end{array}$ & $\begin{array}{ll}13.86 \quad \pm \\
2.3\end{array}$ & $\begin{array}{l}5.22 \\
\pm 2.15\end{array}$ & $3.08 \pm 2.25$ & 2.17 & $\begin{array}{l}1.1 E \\
-02\end{array}$ & 0.65 & $\begin{array}{l}3.0 \mathrm{E} \\
-01\end{array}$ & -0.44 & $\begin{array}{l}6.1 \mathrm{E} \\
-01\end{array}$ & 7.18 & $\begin{array}{l}5.6 E \\
-05\end{array}$ & $\begin{array}{l}182 . \\
95\end{array}$ & $\begin{array}{l}9.1 \mathrm{E} \\
-01\end{array}$ & $\begin{array}{l}- \\
20.3\end{array}$ & $\begin{array}{l}6.4 \mathrm{E} \\
-01\end{array}$ \\
\hline LSP1 & $\begin{array}{l}167.31 \pm \\
5.19\end{array}$ & $\begin{array}{ll}87.86 & \pm \\
11.24 & \end{array}$ & $\begin{array}{l}148.89 \\
\pm 29.32\end{array}$ & $\begin{array}{l}122.31 \\
\pm 16.57\end{array}$ & -0.94 & $\begin{array}{l}2.1 E \\
-03\end{array}$ & -0.2 & $\begin{array}{l}3.3 \mathrm{E} \\
-01\end{array}$ & -0.47 & $\begin{array}{l}2.8 \mathrm{E} \\
-02\end{array}$ & -0.96 & $\begin{array}{l}1.2 \mathrm{E} \\
-03\end{array}$ & -0.2 & $\begin{array}{l}2.2 \mathrm{E} \\
-01\end{array}$ & -0.47 & $\begin{array}{l}3.1 \mathrm{E} \\
-03\end{array}$ \\
\hline LZTS1 & $\begin{array}{ll}1.91 & \pm \\
0.78 & \end{array}$ & $\begin{array}{ll}1.10 & \pm \\
0.15 & \end{array}$ & $\begin{array}{l}1.30 \\
\pm 0.25\end{array}$ & $1.76 \pm 1.24$ & -0.67 & $\begin{array}{l}1.7 \mathrm{E} \\
-01\end{array}$ & -0.44 & $\begin{array}{l}3.4 \mathrm{E} \\
-01\end{array}$ & -0.26 & $\begin{array}{l}6.8 \mathrm{E} \\
-01\end{array}$ & $\begin{array}{l}- \\
23.4 \\
2\end{array}$ & $\begin{array}{l}3.2 \mathrm{E} \\
-01\end{array}$ & -0.33 & $\begin{array}{l}3.6 \mathrm{E} \\
-01\end{array}$ & $\begin{array}{l}- \\
16.8 \\
2\end{array}$ & $\begin{array}{l}3.6 \mathrm{E} \\
-01\end{array}$ \\
\hline$M A O B$ & $\begin{array}{ll}15.09 \quad \pm \\
3.55 & \end{array}$ & $\begin{array}{ll}24.15 \quad \pm \\
2.79 & \end{array}$ & $\begin{array}{l}18.77 \\
\pm 3.74\end{array}$ & $\begin{array}{l}20.41 \\
\pm 4.99\end{array}$ & 0.72 & $\begin{array}{l}4.1 E \\
-02\end{array}$ & 0.33 & $\begin{array}{l}2.9 \mathrm{E} \\
-01\end{array}$ & 0.44 & $\begin{array}{l}2.0 \mathrm{E} \\
-01\end{array}$ & 0.84 & $\begin{array}{l}6.1 \mathrm{E} \\
-02\end{array}$ & 0.25 & $\begin{array}{l}5.4 \mathrm{E} \\
-01\end{array}$ & 0.43 & $\begin{array}{l}2.5 \mathrm{E} \\
-01\end{array}$ \\
\hline MMP13 & $\begin{array}{r}2652.46 \\
\pm 964.2\end{array}$ & $\begin{array}{l}4593.43 \\
\pm 784.9\end{array}$ & $\begin{array}{l}1118.03 \\
\pm 367.87\end{array}$ & $\begin{array}{l}4534.64 \\
\pm 721.70\end{array}$ & 0.85 & $\begin{array}{l}4.4 \mathrm{E} \\
-02\end{array}$ & -1.24 & $\begin{array}{l}1.8 \mathrm{E} \\
-02\end{array}$ & 0.84 & $\begin{array}{l}4.7 E \\
-02\end{array}$ & 0.79 & $\begin{array}{l}1.8 E \\
-02\end{array}$ & -1.25 & $\begin{array}{l}1.2 \mathrm{E} \\
-05\end{array}$ & 0.77 & $\begin{array}{l}2.7 \mathrm{E} \\
-04\end{array}$ \\
\hline MPP3 & $\begin{array}{ll}27.87 \quad \pm \\
4.23\end{array}$ & $\begin{array}{ll}78.36 & \pm \\
17.39 & \end{array}$ & $\begin{array}{l}31.83 \\
\pm 4.07\end{array}$ & $\begin{array}{l}34.35 \\
\pm 7.89\end{array}$ & 1.47 & $\begin{array}{l}7.3 E \\
-04\end{array}$ & 0.2 & $\begin{array}{l}2.7 \mathrm{E} \\
-01\end{array}$ & 0.28 & $\begin{array}{l}2.6 \mathrm{E} \\
-01\end{array}$ & 1.59 & $\begin{array}{l}9.7 \mathrm{E} \\
-06\end{array}$ & 0.05 & $\begin{array}{l}8.6 \mathrm{E} \\
-01\end{array}$ & 0.22 & $\begin{array}{l}3.9 \mathrm{E} \\
-01\end{array}$ \\
\hline NGFR & $\begin{array}{ll}7.90 & \pm \\
4.97 & \end{array}$ & $\begin{array}{ll}13.99 \quad \pm \\
2.31 & \end{array}$ & $\begin{array}{l}6.68 \\
\pm 2.86\end{array}$ & $6.46 \pm 4.98$ & 1.16 & $\begin{array}{l}1.5 \mathrm{E} \\
-01\end{array}$ & -0.04 & $\begin{array}{l}9.6 \mathrm{E} \\
-01\end{array}$ & -0.27 & $\begin{array}{l}7.5 \mathrm{E} \\
-01\end{array}$ & 0.96 & $\begin{array}{l}1.1 \mathrm{E} \\
-01\end{array}$ & -0.96 & $\begin{array}{l}2.9 \mathrm{E} \\
-01\end{array}$ & -1.44 & $\begin{array}{l}1.3 \mathrm{E} \\
-01\end{array}$ \\
\hline NOTCH3 & $\begin{array}{ll}3.49 & \pm \\
2.36 & \end{array}$ & $\begin{array}{ll}6.22 & \pm \\
2.99 & \end{array}$ & $\begin{array}{l}6.65 \\
\pm 3.55\end{array}$ & $\begin{array}{l}11.52 \\
\pm 8.09\end{array}$ & 1.03 & $\begin{array}{l}2.9 \mathrm{E} \\
-01\end{array}$ & 1.14 & $\begin{array}{l}2.4 \mathrm{E} \\
-01\end{array}$ & 1.46 & $\begin{array}{l}2.8 \mathrm{E} \\
-01\end{array}$ & $\begin{array}{l}21.6 \\
5\end{array}$ & $\begin{array}{l}1.3 \mathrm{E} \\
-01\end{array}$ & $\begin{array}{l}18.2 \\
6\end{array}$ & $\begin{array}{l}5.3 \mathrm{E} \\
-01\end{array}$ & 22.4 & $\begin{array}{l}1.0 \mathrm{E} \\
-02\end{array}$ \\
\hline
\end{tabular}




\begin{tabular}{|c|c|c|c|c|c|c|c|c|c|c|c|c|c|c|c|c|}
\hline \multirow{3}{*}{$\begin{array}{l}\text { Gene } \\
\text { Name }\end{array}$} & \multirow{3}{*}{$\begin{array}{c}\text { Base } \\
\text { mean } \\
\text { control }^{1}\end{array}$} & \multirow{3}{*}{$\begin{array}{l}\text { Base } \\
\text { mean } \\
\text { VPA }^{1}\end{array}$} & \multirow{3}{*}{$\begin{array}{l}\text { Base } \\
\text { mean } \\
\text { VPD }^{1}\end{array}$} & \multirow{3}{*}{$\begin{array}{l}\text { Base } \\
\text { mean } \\
\text { TSA }^{1}\end{array}$} & \multicolumn{6}{|c|}{ nSolver $^{\mathrm{TM}}$} & \multicolumn{6}{|c|}{ NanoStringDiff } \\
\hline & & & & & \multicolumn{2}{|c|}{ VPA } & \multicolumn{2}{|c|}{ VPD } & \multicolumn{2}{|c|}{ TSA } & \multicolumn{2}{|c|}{ VPA } & \multicolumn{2}{|c|}{ VPD } & \multicolumn{2}{|c|}{ TSA } \\
\hline & & & & & $\begin{array}{c}\log 2 \\
\text { FC }\end{array}$ & $\begin{array}{r}\text { pval } \\
u^{2}\end{array}$ & $\begin{array}{c}\log 2 \\
\text { FC }\end{array}$ & $\begin{array}{c}\text { pval } \\
u^{2}\end{array}$ & $\begin{array}{c}\log 2 \\
\text { FC }\end{array}$ & $\begin{array}{r}\text { pval } \\
u^{2}\end{array}$ & $\begin{array}{r}\log 2 \\
\text { FC }\end{array}$ & $\begin{array}{r}\text { pval } \\
u^{2}\end{array}$ & $\begin{array}{c}\text { Log2 } \\
\text { FC }\end{array}$ & $\begin{array}{c}\text { pval } \\
u^{2}\end{array}$ & $\begin{array}{c}\log 2 \\
\text { FC }\end{array}$ & $\begin{array}{r}\text { pval } \\
u^{2}\end{array}$ \\
\hline PAK3 & $\begin{array}{ll}93.46 \quad \pm \\
19.31\end{array}$ & $\begin{array}{l}176.60 \pm \\
34.48\end{array}$ & $\begin{array}{l}86.31 \pm 13 . \\
46\end{array}$ & $\begin{array}{l}88.06 \\
\pm 12 . .9\end{array}$ & 0.92 & $\begin{array}{l}7.3 \mathrm{E} \\
-03\end{array}$ & -0.1 & $\begin{array}{l}6.5 \mathrm{E} \\
-01\end{array}$ & -0.07 & $\begin{array}{l}7.4 \mathrm{E} \\
-01\end{array}$ & 0.94 & $\begin{array}{l}3.5 \mathrm{E} \\
-03\end{array}$ & -0.15 & $\begin{array}{l}4.5 \mathrm{E} \\
-01\end{array}$ & -0.1 & $\begin{array}{l}6.0 \mathrm{E} \\
-01\end{array}$ \\
\hline SERPINB2 & $\begin{array}{ll}12.37 \quad \pm \\
4.63 & \end{array}$ & $\begin{array}{ll}22.20 \quad \pm \\
5.18 & \end{array}$ & $3.74 \pm 2.4$ & $\begin{array}{l}18.67 \\
\pm 4.93\end{array}$ & 0.92 & $\begin{array}{l}6.9 \mathrm{E} \\
-02\end{array}$ & -2 & $\begin{array}{l}4.5 \mathrm{E} \\
-02\end{array}$ & 0.66 & $\begin{array}{l}1.6 \mathrm{E} \\
-01\end{array}$ & 0.94 & $\begin{array}{l}5.0 \mathrm{E} \\
-02\end{array}$ & $\begin{array}{l}- \\
23.8 \\
3\end{array}$ & $\begin{array}{l}5.1 \mathrm{E} \\
-05\end{array}$ & 0.48 & $\begin{array}{l}2.3 \mathrm{E} \\
-01\end{array}$ \\
\hline SHANK3 & $\begin{array}{ll}13.88 \quad \pm \\
7.86 & \end{array}$ & $\begin{array}{ll}22.50 \quad \pm \\
4.72\end{array}$ & $\begin{array}{l}21.07 \\
\pm 0.87\end{array}$ & $8.75 \pm 2.73$ & 1.26 & $\begin{array}{l}2.9 \mathrm{E} \\
-01\end{array}$ & 1.2 & $\begin{array}{l}3.0 \mathrm{E} \\
-01\end{array}$ & -0.16 & $\begin{array}{l}8.8 \mathrm{E} \\
-01\end{array}$ & 0.73 & $\begin{array}{l}1.2 \mathrm{E} \\
-01\end{array}$ & 0.44 & $\begin{array}{l}2.6 \mathrm{E} \\
-01\end{array}$ & -1.18 & $\begin{array}{l}2.0 \mathrm{E} \\
-02\end{array}$ \\
\hline SNAP91 & $\begin{array}{l}143.26 \pm \\
9.77\end{array}$ & $\begin{array}{ll}230.51 & \pm \\
11.62 & \end{array}$ & $\begin{array}{l}173.60 \pm 9 . \\
02\end{array}$ & $\begin{array}{l}107.60 \pm 23 \\
.93\end{array}$ & 0.69 & $\begin{array}{l}1.2 \mathrm{E} \\
-04\end{array}$ & 0.28 & $\begin{array}{l}9.6 \mathrm{E} \\
-03\end{array}$ & -0.45 & $\begin{array}{l}1.2 \mathrm{E} \\
-01\end{array}$ & 0.7 & $\begin{array}{l}1.3 E \\
-02\end{array}$ & 0.26 & $\begin{array}{l}5.0 \mathrm{E} \\
-02\end{array}$ & -0.45 & $\begin{array}{l}1.4 \mathrm{E} \\
-02\end{array}$ \\
\hline VGF & $\begin{array}{ll}22.73 \quad \pm \\
6.45 & \end{array}$ & $\begin{array}{l}111.87 \pm \\
33.3\end{array}$ & $\begin{array}{l}27.11 \\
\pm 9.58\end{array}$ & $\begin{array}{l}51.84 \\
\pm 9.04\end{array}$ & 2.3 & $\begin{array}{l}5.8 E \\
-04\end{array}$ & 0.23 & $\begin{array}{l}5.7 \mathrm{E} \\
-01\end{array}$ & 1.23 & $\begin{array}{l}9.3 E \\
-03\end{array}$ & 2.44 & $\begin{array}{l}8.4 \mathrm{E} \\
-10\end{array}$ & 0.1 & $\begin{array}{l}7.6 \mathrm{E} \\
-01\end{array}$ & 1.22 & $\begin{array}{l}1.4 \mathrm{E} \\
-06\end{array}$ \\
\hline WNT6 & $\begin{array}{ll}1.91 & \pm \\
0.78 & \end{array}$ & $\begin{array}{ll}5.77 & \pm \\
2.17 & \end{array}$ & $8.31 \pm 3.99$ & $2.52 \pm 1.52$ & 1.6 & $\begin{array}{l}2.2 \mathrm{E} \\
-02\end{array}$ & 2.05 & $\begin{array}{l}1.7 \mathrm{E} \\
-02\end{array}$ & 0.21 & $\begin{array}{l}7.7 \mathrm{E} \\
-01\end{array}$ & $\begin{array}{l}24.8 \\
3\end{array}$ & $\begin{array}{l}7.9 \mathrm{E} \\
-02\end{array}$ & $\begin{array}{l}26.7 \\
3\end{array}$ & $\begin{array}{l}3.8 \mathrm{E} \\
-02\end{array}$ & $\begin{array}{l}- \\
16.8 \\
2\end{array}$ & $\begin{array}{l}4.9 \mathrm{E} \\
-01\end{array}$ \\
\hline ZCCHC12 & $\begin{array}{ll}33.68 \quad \pm \\
9.89 & \end{array}$ & $\begin{array}{ll}86.28 \quad \pm \\
7.44 & \end{array}$ & $\begin{array}{l}31.37 \\
\pm 10.99\end{array}$ & $\begin{array}{l}12.97 \\
\pm 5.54\end{array}$ & 1.41 & $\begin{array}{l}5.2 E \\
-03\end{array}$ & -0.14 & $\begin{array}{l}7.2 \mathrm{E} \\
-01\end{array}$ & -1.47 & $\begin{array}{l}2.1 \mathrm{E} \\
-02\end{array}$ & 1.47 & $\begin{array}{l}3.1 E \\
-05\end{array}$ & -0.22 & $\begin{array}{l}4.7 \mathrm{E} \\
-01\end{array}$ & -1.71 & $\begin{array}{l}7.1 E \\
-07\end{array}$ \\
\hline
\end{tabular}

${ }^{1}$ Base mean control, base mean VPA, base mean VPD and base mean TSA refer to the mean of normalized counts from four replicates each of untreated, VPA-treated, VPD-treated and TSA-treated samples in Run1, respectively. Fold difference between the untreated vs VPA-treated, untreated vs VPD-treated and untreated vs TSA-treated are shown.

${ }^{2}$ Bold values indicate the significant genes with $\mathrm{p}$-val $<0.05$. 
Table 5: nCounter® $\log 2$ fold change and p-values for VPA, VPD and CI994-treated RN46A cells in Run2.

\begin{tabular}{|c|c|c|c|c|c|c|c|c|c|c|c|c|c|c|c|c|}
\hline \multirow{3}{*}{$\begin{array}{l}\text { Gene } \\
\text { Name }\end{array}$} & \multirow{3}{*}{$\begin{array}{c}\text { Base } \\
\text { mean } \\
\text { Control }^{1}\end{array}$} & \multirow{3}{*}{$\begin{array}{l}\text { Base } \\
\text { mean } \\
\text { VPA }^{1}\end{array}$} & \multirow{3}{*}{$\begin{array}{l}\text { Base } \\
\text { mean } \\
\text { VPD }^{1}\end{array}$} & \multirow{3}{*}{$\begin{array}{c}\text { Base } \\
\text { mean } \\
\text { CI994' }\end{array}$} & \multicolumn{6}{|c|}{ nSolver $^{\mathrm{TM}}$} & \multicolumn{6}{|c|}{ NanoStringDiff } \\
\hline & & & & & \multicolumn{2}{|c|}{ VPA } & \multicolumn{2}{|c|}{ VPD } & \multicolumn{2}{|c|}{ CI994 } & \multicolumn{2}{|c|}{ VPA } & \multicolumn{2}{|c|}{ VPD } & \multicolumn{2}{|c|}{ CI994 } \\
\hline & & & & & $\begin{array}{c}\log 2 \\
\text { FC }\end{array}$ & $\begin{array}{c}\text { pval } \\
u^{2}\end{array}$ & $\begin{array}{l}\text { Log } \\
\text { 2FC }\end{array}$ & $\begin{array}{c}\text { pval } \\
u^{2}\end{array}$ & $\begin{array}{l}\text { Log } \\
2 \mathrm{FC}\end{array}$ & $\begin{array}{c}\text { pval } \\
u^{2}\end{array}$ & $\begin{array}{l}\log \\
2 \mathrm{FC}\end{array}$ & $\begin{array}{c}\text { pval } \\
u^{2}\end{array}$ & $\begin{array}{l}\text { Log } \\
\text { 2FC }\end{array}$ & $\begin{array}{c}\text { pval } \\
u^{2}\end{array}$ & $\begin{array}{l}\text { Log } \\
\text { 2FC }\end{array}$ & $\begin{array}{c}\text { pval } \\
u^{2}\end{array}$ \\
\hline$A D A M 23$ & $\begin{array}{l}37.50 \pm \\
15.26\end{array}$ & $\begin{array}{l}148.26 \pm \\
27.84\end{array}$ & $\begin{array}{l}74.90 \\
\pm 32.48\end{array}$ & $\begin{array}{l}40.83 \\
\pm 11.76\end{array}$ & 1.66 & $\begin{array}{l}1.60 \\
\text { E-02 }\end{array}$ & 0.79 & $\begin{array}{l}1.50 \\
\text { E-01 }\end{array}$ & 0.12 & $\begin{array}{l}7.60 \\
\text { E-01 }\end{array}$ & 1.76 & $\begin{array}{l}1.30 \\
\text { E-05 }\end{array}$ & 0.85 & $\begin{array}{l}1.80 \\
\text { E-02 }\end{array}$ & 0.09 & $\begin{array}{l}7.70 \\
\text { E-01 }\end{array}$ \\
\hline$A D G R B 2$ & $\begin{array}{l}55.48 \pm \\
12.95\end{array}$ & $\begin{array}{l}241.17 \pm \\
12.21\end{array}$ & $\begin{array}{l}72.21 \\
\pm 28.52\end{array}$ & $\begin{array}{l}71.14 \\
\pm 9.8\end{array}$ & 1.88 & $\begin{array}{l}7.90 \\
\text { E-03 }\end{array}$ & 0.28 & $\begin{array}{l}5.30 \\
\text { E-01 }\end{array}$ & 0.3 & $\begin{array}{l}2.60 \\
\text { E-01 }\end{array}$ & 1.98 & $\begin{array}{l}2.10 \\
\text { E-09 }\end{array}$ & 0.35 & $\begin{array}{l}3.20 \\
\text { E-01 }\end{array}$ & 0.34 & $\begin{array}{l}2.10 \\
\text { E-01 }\end{array}$ \\
\hline CACNAIB & $\begin{array}{l}1.33 \pm \\
0.25\end{array}$ & $\begin{array}{l}29.80 \pm \\
17.19\end{array}$ & $\begin{array}{l}24.37 \\
\pm 21.44\end{array}$ & $\begin{array}{l}1.00 \pm \\
0.0\end{array}$ & 2.25 & $\begin{array}{l}2.80 \\
\text { E-02 }\end{array}$ & 1.78 & $\begin{array}{l}1.80 \\
\text { E-01 }\end{array}$ & -1.41 & $\begin{array}{l}2.50 \\
\text { E-01 }\end{array}$ & 3.74 & $\begin{array}{l}2.00 \\
\text { E-05 }\end{array}$ & 3.39 & $\begin{array}{l}2.00 \\
\text { E-06 }\end{array}$ & $\begin{array}{l}- \\
25.0 \\
1\end{array}$ & $\begin{array}{l}2.10 \\
\text { E-01 }\end{array}$ \\
\hline$C D K N 1 C$ & $\begin{array}{l}113.15 \pm \\
19.3\end{array}$ & $\begin{array}{l}133.84 \pm \\
25.09\end{array}$ & $\begin{array}{l}162.22 \\
\pm 36.3\end{array}$ & $\begin{array}{l}61.78 \\
\pm 23.42\end{array}$ & 0.18 & $\begin{array}{l}5.10 \\
\text { E-01 }\end{array}$ & 0.47 & $\begin{array}{l}1.40 \\
\text { E-01 }\end{array}$ & -0.81 & $\begin{array}{l}1.20 \\
\text { E-01 }\end{array}$ & 0.22 & $\begin{array}{l}5.10 \\
\text { E-01 }\end{array}$ & 0.5 & $\begin{array}{l}1.30 \\
\text { E-01 }\end{array}$ & -0.77 & $\begin{array}{l}9.00 \\
\text { E-03 }\end{array}$ \\
\hline CNTN1 & $\begin{array}{l}346.69 \pm \\
58.78\end{array}$ & $\begin{array}{l}598.86 \pm \\
67.27\end{array}$ & $\begin{array}{l}351.12 \\
\pm 93.5\end{array}$ & $\begin{array}{l}468.11 \\
\pm 81.9\end{array}$ & 0.77 & $\begin{array}{l}2.80 \\
\text { E-02 }\end{array}$ & 0 & $\begin{array}{l}1.00 \\
E+00\end{array}$ & 0.42 & \begin{tabular}{|l|}
1.70 \\
E-01
\end{tabular} & 0.78 & $\begin{array}{l}8.20 \\
\text { E-03 }\end{array}$ & 0.02 & $\begin{array}{l}9.40 \\
\text { E-01 }\end{array}$ & 0.43 & $\begin{array}{l}7.20 \\
\text { E-02 }\end{array}$ \\
\hline$E R B B 3$ & $\begin{array}{l}1.33 \pm \\
0.25\end{array}$ & $\begin{array}{l}15.53 \pm \\
3.41\end{array}$ & $\begin{array}{l}1.53 \\
\pm 0.44\end{array}$ & $\begin{array}{l}1.00 \pm \\
0.0\end{array}$ & 3.09 & $\begin{array}{l}4.60 \\
\text { E-02 }\end{array}$ & 1 & $\begin{array}{l}4.00 \\
\text { E-01 }\end{array}$ & 1.85 & $\begin{array}{l}1.10 \\
\text { E-01 }\end{array}$ & $\begin{array}{l}27.1 \\
9\end{array}$ & $\begin{array}{l}5.30 \\
\text { E-07 }\end{array}$ & $\begin{array}{l}24.7 \\
3\end{array}$ & $\begin{array}{l}3.90 \\
\text { E-01 }\end{array}$ & $\begin{array}{l}26.5 \\
1\end{array}$ & $\begin{array}{l}1.00 \\
\text { E-02 }\end{array}$ \\
\hline GNAII & $\begin{array}{l}1.33 \pm \\
0.25\end{array}$ & $\begin{array}{l}18.23 \pm \\
11.98\end{array}$ & $\begin{array}{l}1.16 \\
\pm 0.17\end{array}$ & $\begin{array}{l}1.00 \pm \\
0.0\end{array}$ & 3.63 & $\begin{array}{l}2.30 \\
\text { E-02 }\end{array}$ & 1.9 & $\begin{array}{l}1.10 \\
\text { E-01 }\end{array}$ & 0.47 & \begin{tabular}{|l|}
7.00 \\
E-01
\end{tabular} & $\begin{array}{l}29.6 \\
7\end{array}$ & $\begin{array}{l}4.70 \\
\text { E-07 }\end{array}$ & $\begin{array}{l}24.1 \\
9\end{array}$ & $\begin{array}{l}4.20 \\
\text { E-01 }\end{array}$ & $\begin{array}{l}182 . \\
48\end{array}$ & $\begin{array}{l}6.30 \\
\text { E-01 }\end{array}$ \\
\hline
\end{tabular}




\begin{tabular}{|c|c|c|c|c|c|c|c|c|c|c|c|c|c|c|c|c|}
\hline \multirow{3}{*}{$\begin{array}{l}\text { Gene } \\
\text { Name }\end{array}$} & \multirow{3}{*}{$\begin{array}{c}\text { Base } \\
\text { mean } \\
\text { Control }^{1}\end{array}$} & \multirow{3}{*}{$\begin{array}{c}\text { Base } \\
\text { mean } \\
\text { VPA }^{1}\end{array}$} & \multirow{3}{*}{$\begin{array}{l}\text { Base } \\
\text { mean } \\
\text { VPD' }^{1}\end{array}$} & \multirow{3}{*}{$\begin{array}{c}\text { Base } \\
\text { mean } \\
\text { CI994 }\end{array}$} & \multicolumn{6}{|c|}{ nSolver $^{\mathrm{TM}}$} & \multicolumn{6}{|c|}{ NanoStringDiff } \\
\hline & & & & & \multicolumn{2}{|c|}{ VPA } & \multicolumn{2}{|c|}{ VPD } & \multicolumn{2}{|c|}{ CI994 } & \multicolumn{2}{|c|}{ VPA } & \multicolumn{2}{|c|}{ VPD } & \multicolumn{2}{|c|}{ CI994 } \\
\hline & & & & & $\begin{array}{c}\log 2 \\
\text { FC }\end{array}$ & $\begin{array}{c}\text { pval } \\
u^{2}\end{array}$ & $\begin{array}{l}\text { Log } \\
2 F C\end{array}$ & $\begin{array}{c}\text { pval } \\
u^{2}\end{array}$ & $\begin{array}{l}\text { Log } \\
2 \mathrm{FC}\end{array}$ & $\begin{array}{c}\text { pval } \\
u^{2}\end{array}$ & $\begin{array}{l}\text { Log } \\
2 F C\end{array}$ & $\begin{array}{r}\text { pval } \\
\text { ue }^{2}\end{array}$ & $\begin{array}{l}\text { Log } \\
\text { 2FC }\end{array}$ & $\begin{array}{c}\text { pval } \\
u^{2}\end{array}$ & $\begin{array}{l}\text { Log } \\
2 \mathrm{FC}\end{array}$ & $\begin{array}{c}\text { pval } \\
u^{2}\end{array}$ \\
\hline$I G F 2$ & $\begin{array}{l}1.33 \quad \pm \\
0.25\end{array}$ & $\begin{array}{l}5.91 \quad \pm \\
3.42\end{array}$ & $\begin{array}{l}11.35 \\
\pm 11.49\end{array}$ & $\begin{array}{l}1.00 \pm \\
0.0\end{array}$ & 2.62 & $\begin{array}{l}1.70 \\
\text { E-01 }\end{array}$ & 2.96 & \begin{tabular}{|l|}
2.20 \\
E-01
\end{tabular} & 0.58 & $\begin{array}{l}6.10 \\
\text { E-01 }\end{array}$ & $\begin{array}{l}29.5 \\
9\end{array}$ & $\begin{array}{l}2.70 \\
\text { E-04 }\end{array}$ & $\begin{array}{l}30.4 \\
9\end{array}$ & $\begin{array}{l}8.50 \\
\text { E-07 }\end{array}$ & $\begin{array}{l}- \\
64.3 \\
7\end{array}$ & $\begin{array}{l}4.90 \\
\text { E-01 }\end{array}$ \\
\hline LINGOI & $\begin{array}{l}1.33 \quad \pm \\
0.25\end{array}$ & $\begin{array}{l}10.72 \pm \\
11.07\end{array}$ & $\begin{array}{l}25.79 \\
\pm 25.73\end{array}$ & $\begin{array}{l}1.00 \pm \\
0.0\end{array}$ & 2.27 & $\begin{array}{l}6.60 \\
\text { E-02 }\end{array}$ & 2.65 & \begin{tabular}{|l|}
1.00 \\
E-01
\end{tabular} & -1.09 & $\begin{array}{l}3.50 \\
\text { E-01 }\end{array}$ & $\begin{array}{l}34.6 \\
6\end{array}$ & $\begin{array}{l}1.60 \\
\text { E-04 }\end{array}$ & $\begin{array}{l}25.9 \\
4\end{array}$ & $\begin{array}{l}2.90 \\
\text { E-09 }\end{array}$ & $\begin{array}{l}- \\
179 . \\
2\end{array}$ & $\begin{array}{l}6.10 \\
\text { E-01 }\end{array}$ \\
\hline LSPI & $\begin{array}{l}698.88 \quad \pm \\
49.72\end{array}$ & $\begin{array}{l}286.21 \pm \\
21.02\end{array}$ & $\begin{array}{l}229.45 \\
\pm 28.71\end{array}$ & $\begin{array}{l}589.43 \\
\pm 23.48\end{array}$ & -1.26 & $\begin{array}{l}2.80 \\
\text { E-04 }\end{array}$ & -1.55 & \begin{tabular}{|l|}
9.40 \\
E-04
\end{tabular} & -0.24 & \begin{tabular}{|l|}
5.70 \\
E-02
\end{tabular} & -1.27 & $\begin{array}{l}\mathbf{4 . 0 0} \\
\text { E-07 }\end{array}$ & -1.57 & $\begin{array}{l}5.60 \\
\text { E-07 }\end{array}$ & -0.24 & $\begin{array}{l}1.90 \\
\text { E-01 }\end{array}$ \\
\hline LZTS1 & $\begin{array}{l}1.33 \quad \pm \\
0.25\end{array}$ & $\begin{array}{l}12.61 \pm \\
6.41\end{array}$ & $\begin{array}{l}9.35 \\
\pm 11.76\end{array}$ & $\begin{array}{l}1.00 \pm \\
0.0\end{array}$ & 3.54 & $\begin{array}{l}3.10 \\
\text { E-02 }\end{array}$ & 1.83 & \begin{tabular}{|l|}
3.60 \\
E-01
\end{tabular} & -0.23 & $\begin{array}{l}8.50 \\
\text { E-01 }\end{array}$ & $\begin{array}{l}23.9 \\
2\end{array}$ & $\begin{array}{l}5.20 \\
\text { E-07 }\end{array}$ & $\begin{array}{l}26.2 \\
1\end{array}$ & $\begin{array}{l}5.00 \\
\text { E-04 }\end{array}$ & $\begin{array}{l}- \\
159 . \\
23\end{array}$ & $\begin{array}{l}5.00 \\
\text { E-01 }\end{array}$ \\
\hline$M A O B$ & $\begin{array}{l}67.00 \quad \pm \\
11.19\end{array}$ & $\begin{array}{l}376.47 \pm \\
23.73\end{array}$ & $\begin{array}{l}64.88 \\
\pm 8.91\end{array}$ & $\begin{array}{l}138.75 \\
\pm 23.76\end{array}$ & 2.27 & $\begin{array}{l}1.50 \\
\text { E-03 }\end{array}$ & -0.01 & \begin{tabular}{|l|}
9.70 \\
E-01
\end{tabular} & 0.9 & \begin{tabular}{|l|}
1.40 \\
E-02
\end{tabular} & 2.35 & $\begin{array}{l}1.10 \\
\text { E-14 }\end{array}$ & -0.04 & $\begin{array}{l}9.20 \\
\text { E-01 }\end{array}$ & 0.97 & $\begin{array}{l}1.80 \\
\text { E-04 }\end{array}$ \\
\hline$M M P 13$ & $\begin{array}{l}3312.56 \\
\pm 384.81\end{array}$ & $\begin{array}{l}5281.11 \\
\pm 300.02\end{array}$ & $\begin{array}{l}2207.43 \\
\pm 609.44\end{array}$ & $\begin{array}{l}4243.11 \\
\pm 368.70\end{array}$ & 0.68 & $\begin{array}{l}1.40 \\
\text { E-02 }\end{array}$ & -0.62 & \begin{tabular}{|l|}
1.30 \\
E-01
\end{tabular} & 0.36 & \begin{tabular}{|l|}
7.10 \\
E-02
\end{tabular} & 0.67 & $\begin{array}{l}5.70 \\
\text { E-03 }\end{array}$ & -0.58 & $\begin{array}{l}5.50 \\
\text { E-02 }\end{array}$ & 0.36 & $\begin{array}{l}6.90 \\
\text { E-02 }\end{array}$ \\
\hline$M P P 3$ & $\begin{array}{l}3.32 \quad \pm \\
2.80\end{array}$ & $\begin{array}{l}23.32 \pm \\
14.69\end{array}$ & $\begin{array}{l}37.30 \\
\pm 37.83\end{array}$ & $\begin{array}{l}3.53 \\
\pm 3.58\end{array}$ & 1 & $\begin{array}{l}1.10 \\
\text { E-01 }\end{array}$ & 1.26 & \begin{tabular}{|l|}
2.60 \\
E-01
\end{tabular} & -0.33 & $\begin{array}{l}4.50 \\
\text { E-01 }\end{array}$ & 1.63 & $\begin{array}{l}1.20 \\
\text { E-02 }\end{array}$ & 2.18 & $\begin{array}{l}1.20 \\
\text { E-05 }\end{array}$ & -0.29 & $\begin{array}{l}6.60 \\
\text { E-01 }\end{array}$ \\
\hline
\end{tabular}




\begin{tabular}{|c|c|c|c|c|c|c|c|c|c|c|c|c|c|c|c|c|}
\hline \multirow{3}{*}{$\begin{array}{l}\text { Gene } \\
\text { Name }\end{array}$} & \multirow{3}{*}{$\begin{array}{c}\text { Base } \\
\text { mean } \\
\text { Control }^{1}\end{array}$} & \multirow{3}{*}{$\begin{array}{l}\text { Base } \\
\text { mean } \\
\text { VPA }^{1}\end{array}$} & \multirow{3}{*}{$\begin{array}{l}\text { Base } \\
\text { mean } \\
\text { VPD }^{1}\end{array}$} & \multirow{3}{*}{$\begin{array}{c}\text { Base } \\
\text { mean } \\
\text { CI994 }\end{array}$} & \multicolumn{6}{|c|}{ nSolver ${ }^{\mathrm{TM}}$} & \multicolumn{6}{|c|}{ NanoStringDiff } \\
\hline & & & & & \multicolumn{2}{|c|}{ VPA } & \multicolumn{2}{|c|}{ VPD } & \multicolumn{2}{|c|}{ CI994 } & \multicolumn{2}{|c|}{ VPA } & \multicolumn{2}{|c|}{ VPD } & \multicolumn{2}{|c|}{ CI994 } \\
\hline & & & & & $\begin{array}{c}\log 2 \\
\text { FC }\end{array}$ & $\begin{array}{r}\text { pval } \\
\text { ue }^{2}\end{array}$ & $\begin{array}{l}\log \\
2 \mathrm{FC}\end{array}$ & $\begin{array}{c}\text { pval } \\
u^{2}\end{array}$ & $\begin{array}{l}\log \\
2 \mathrm{FC}\end{array}$ & $\begin{array}{c}\text { pval } \\
u^{2}\end{array}$ & $\begin{array}{l}\log \\
2 \mathrm{FC}\end{array}$ & $\begin{array}{c}\text { pval } \\
u^{2}\end{array}$ & $\begin{array}{l}\log \\
2 \mathrm{FC}\end{array}$ & $\begin{array}{c}\text { pval } \\
u^{2}\end{array}$ & $\begin{array}{l}\text { Log } \\
2 \mathrm{FC}\end{array}$ & $\begin{array}{r}\text { pval } \\
u^{2}\end{array}$ \\
\hline NGFR & $\begin{array}{ll}64.65 & \pm \\
16.67 & \end{array}$ & $\begin{array}{ll}381.39 \quad \pm \\
57.17\end{array}$ & $\begin{array}{l}98.63 \\
\pm 33.46\end{array}$ & $\begin{array}{l}111.72 \\
\pm 7.21\end{array}$ & 2.33 & $\begin{array}{l}1.60 \\
\text { E-03 }\end{array}$ & 0.51 & $\begin{array}{l}2.20 \\
\text { E-01 }\end{array}$ & 0.69 & $\begin{array}{l}7.40 \\
\text { E-02 }\end{array}$ & 2.41 & $\begin{array}{l}1.20 \\
\text { E-11 }\end{array}$ & 0.54 & $\begin{array}{l}1.10 \\
\text { E-01 }\end{array}$ & 0.7 & $\begin{array}{l}6.60 \\
\text { E-03 }\end{array}$ \\
\hline NOTCH3 & $\begin{array}{ll}27.59 \quad \pm \\
9.5\end{array}$ & $\begin{array}{l}118.30 \pm \\
24.31\end{array}$ & $\begin{array}{l}51.77 \\
\pm 28.42\end{array}$ & $\begin{array}{r}36.14 \\
+5.10\end{array}$ & 1.64 & $\begin{array}{l}7.30 \\
\text { E-03 }\end{array}$ & 0.58 & $\begin{array}{l}3.50 \\
\text { E-01 }\end{array}$ & 0.28 & $\begin{array}{l}3.70 \\
\text { E-01 }\end{array}$ & 1.83 & $\begin{array}{l}7.40 \\
\text { E-06 }\end{array}$ & 0.77 & $\begin{array}{l}.20 \\
\text { E-02 }\end{array}$ & 0.35 & $\begin{array}{l}2.80 \\
\text { E-01 }\end{array}$ \\
\hline$P A K 3$ & $\begin{array}{ll}29.12 \quad \pm \\
3.11\end{array}$ & $\begin{array}{ll}82.33 \quad \pm \\
7.39\end{array}$ & $\begin{array}{l}44.48 \\
\pm 10.71\end{array}$ & $\begin{array}{l}44.83 \\
\pm 3.5\end{array}$ & 1.09 & $\begin{array}{l}1.50 \\
\text { E-02 }\end{array}$ & 0.45 & $\begin{array}{l}1.20 \\
\text { E-01 }\end{array}$ & 0.43 & $\begin{array}{l}1.50 \\
\text { E-02 }\end{array}$ & 1.26 & $\begin{array}{l}7.80 \\
\text { E-04 }\end{array}$ & 0.49 & $\begin{array}{l}1.90 \\
\text { E-01 }\end{array}$ & 0.49 & $\begin{array}{l}9.60 \\
\text { E-02 }\end{array}$ \\
\hline SERPINB2 & $\begin{array}{l}1349.53 \\
\pm 67.66\end{array}$ & $\begin{array}{l}2715.63 \\
\pm 182.07\end{array}$ & $\begin{array}{r}1305.58 \\
\pm 363.04\end{array}$ & $\begin{array}{l}1761.81 \\
\pm 384.84\end{array}$ & 1 & $\begin{array}{l}4.70 \\
\text { E-04 }\end{array}$ & -0.1 & $\begin{array}{l}7.60 \\
\text { E-01 }\end{array}$ & 0.34 & $\begin{array}{l}2.90 \\
\text { E-01 }\end{array}$ & 1 & $\begin{array}{l}1.10 \\
\text { E-05 }\end{array}$ & -0.05 & $\begin{array}{l}8.80 \\
\text { E-01 }\end{array}$ & 0.38 & $\begin{array}{l}9.70 \\
\text { E-02 }\end{array}$ \\
\hline SHANK3 & $\begin{array}{ll}1.33 & \pm \\
0.25 & \end{array}$ & $\begin{array}{ll}2.18 & \pm \\
1.34 & \end{array}$ & $\begin{array}{l}2.30 \\
\pm 1.78\end{array}$ & $\begin{array}{ll}1.00 \quad \pm \\
0.0\end{array}$ & 2.11 & $\begin{array}{l}5.90 \\
\text { E-02 }\end{array}$ & 1.29 & \begin{tabular}{|l|}
3.90 \\
E-01
\end{tabular} & 1.7 & $\begin{array}{l}1.80 \\
\text { E-03 }\end{array}$ & $\begin{array}{l}27.3 \\
7\end{array}$ & $\begin{array}{l}3.50 \\
\text { E-02 }\end{array}$ & 20.6 & $\begin{array}{l}6.20 \\
\text { E-01 }\end{array}$ & $\begin{array}{l}141 . \\
35\end{array}$ & $\begin{array}{l}6.40 \\
\text { E-01 }\end{array}$ \\
\hline SNAP91 & $\begin{array}{ll}33.98 & \pm \\
11.26 & \end{array}$ & $\begin{array}{ll}89.24 & \pm \\
16.86 & \end{array}$ & $\begin{array}{l}66.56 \\
\pm 30.94\end{array}$ & $\begin{array}{r}23.70 \\
\pm 7.71\end{array}$ & 1.07 & $\begin{array}{l}1.80 \\
\text { E-02 }\end{array}$ & 0.67 & $\begin{array}{l}2.60 \\
\text { E-01 }\end{array}$ & -0.36 & $\begin{array}{l}2.80 \\
\text { E-01 }\end{array}$ & 1.2 & $\begin{array}{l}1.90 \\
\text { E-03 }\end{array}$ & 0.83 & $\begin{array}{l}2.30 \\
\text { E-02 }\end{array}$ & -0.4 & $\begin{array}{l}2.30 \\
\text { E-01 }\end{array}$ \\
\hline$V G F$ & $\begin{array}{ll}44.57 & \pm \\
33.22 & \end{array}$ & $\begin{array}{ll}123.27 \quad \pm \\
47.85\end{array}$ & $\begin{array}{l}86.71 \\
\pm 29.54\end{array}$ & $\begin{array}{l}69.35 \\
\pm 11.62\end{array}$ & 1.31 & $\begin{array}{l}1.20 \\
\text { E-01 }\end{array}$ & 0.93 & \begin{tabular}{|l|}
2.30 \\
E-01
\end{tabular} & 0.69 & $\begin{array}{l}3.20 \\
\text { E-01 }\end{array}$ & 1.28 & $\begin{array}{l}2.50 \\
\text { E-02 }\end{array}$ & 0.77 & $\begin{array}{l}2.70 \\
\text { E-02 }\end{array}$ & 0.48 & $\begin{array}{l}1.90 \\
\text { E-01 }\end{array}$ \\
\hline WNT6 & $\begin{array}{l}26.70 \quad \pm \\
3.42\end{array}$ & $\begin{array}{l}149.11 \pm \\
8.65\end{array}$ & $\begin{array}{l}55.41 \\
\pm 17.14\end{array}$ & $\begin{array}{l}46.90 \\
\pm 11.48\end{array}$ & 1.97 & $\begin{array}{l}1.70 \\
\text { E-04 }\end{array}$ & 0.76 & $\begin{array}{l}5.60 \\
\text { E-02 }\end{array}$ & 0.53 & $\begin{array}{l}1.40 \\
\text { E-01 }\end{array}$ & 2.18 & $\begin{array}{l}1.70 \\
\text { E-10 }\end{array}$ & 0.88 & $\begin{array}{l}1.90 \\
\text { E-02 }\end{array}$ & 0.68 & $\begin{array}{l}3.30 \\
\text { E-02 }\end{array}$ \\
\hline $\mathrm{ZCCHC12}$ & $\begin{array}{l}28.09 \pm \\
11.78\end{array}$ & $\begin{array}{l}198.19 \pm \\
31.0\end{array}$ & $\begin{array}{l}30.43 \\
\pm 7.65\end{array}$ & $\begin{array}{l}59.88 \\
\pm 12.09\end{array}$ & 2.35 & $\begin{array}{l}7.20 \\
\text { E-03 }\end{array}$ & 0.18 & $\begin{array}{l}6.40 \\
\text { E-01 }\end{array}$ & 0.84 & $\begin{array}{l}1.00 \\
\text { E-01 }\end{array}$ & 2.45 & $\begin{array}{l}1.00 \\
\text { E-09 }\end{array}$ & 0.05 & $\begin{array}{l}9.00 \\
\text { E-01 }\end{array}$ & 0.85 & $\begin{array}{l}6.60 \\
\text { E-03 }\end{array}$ \\
\hline
\end{tabular}


1Base mean control, base mean VPA, base mean VPD and base mean C1994 refer to the mean of normalized counts from three replicates each of untreated, VPA-treated, VPD-treated and CI994-treated samples in Run2, respectively. Fold difference between the untreated vs VPA-treated, untreated vs VPD-treated and untreated vs CI994-treated are shown.

${ }^{2}$ Bold values indicate the significant genes with $p$-val $<0.05$. 